\title{
FATHER ARSENIE PAPACIOC AND THE PROPER ARRANGEMENT OF SPIRITUAL LIFE. GLIMPSES OF HIS EXPERIENCES IN THE COMMUNIST PRISONS
}

\author{
Ph.D. Ion Marian Croitoru \\ Faculty of Theology and Sciences of Education, \\ "Valahia" University of Târgovişte, \\ ROMANIA, \\ E-mail: ioncroitoru@yahoo.fr
}

\begin{abstract}
Father Arsenie Papacioc lived his life in the middle of many transformations of the Romanian nation, passing from the "fascination" of the Legionary Movement to "the foolishness" of monastic life. He had the experience of the prisons of different periods of the regimes in Romania, but also of the wilderness, getting to represent the life of the Orthodox Church prior to, under and after the communism. For this reason, Father Arsenie's life is intertwined with the lives of many remarkable cultural, political and especially ecclesial characters of the history of the Romanian society, from the Patriarch Justinian to the Archimandrites Cleopa Ilie and Ioanichie Bălan, from the community of the monasteries Cozia, Tismana (Cioclovina Skete), Sihăstria, Antim, Slatina, Neamț, Cheia, Căldărușani, Dintr-un Lemn, Cernica and Techirghiol to the members of the Burning Bush Movement, from the multitude of believers to hierarchs of the Orthodox Church of Romania, from the parish of Filea de Jos (then Filea de Sus, as well) and those of Orthodox faith to those of other religious denominations and convictions. Thus, Father Arsenie marked the epoch he lived in by the proper arrangement of his spiritual life at the measure of holiness, receiving many charismata from the God glorified as the Holy Trinity.
\end{abstract}

Keywords: Father Arsenie Papacioc; communist regime; prisons; wilderness; spiritual life; Orthodox Church; monastic life; The Burning Bush Movement (Mișcarea Rugul Aprins);

\section{INTRODUCTION}

The recollection of the persons who have marked our lives is combined with emotions and feelings animated by honour and gratitude, vivid memories and the formation of milestones by the advice received. Due to these aspects, on the one hand, it is not desired to diminish in any way their personality, and, on the other hand, one ought to cultivate humility and objectiveness, so as not to interpret the things left behind on paper in a manner alien to the spiritual state they had in accordance with the teaching of the Orthodox Church. The abundance of the experiences lived by their side is permanent spiritual food, meant to also satisfy the hunger of those around us, especially when one can note, with great joy, that others, too, have already fed on the same spiritual food for a long while. For this reason, I have chosen to evoke Father Arsenie Papacioc, in the homage year of the Romanian Patriarchate dedicated to those who suffered in the prisons of the communist regime to 
defend the faith in Jesus Christ and the perennial values of the human society ${ }^{1}$, not just relying on the presentation of my own series of experiences by the side of the great Black Sea Spiritual Father, but also based on already published testimonies, some of them narrated to me personally as well by Father Arsenie himself, in the course of time ${ }^{2}$.

\section{BIOGRAPHIC MILESTONES}

Born on 15 August $1914^{3}$ and passed into the life beyond the grave on 19 July 2011, Father Arsenie Papacioc came, according to his paternal lineage, from a family of Aromanians of Macedonia, arrived and settled in Misleanu, nowadays Perieți Village, of Ialomița County ${ }^{4}$. The Father's great-grandfather was a priest in Macedonia and had a long beard, which would explain the origin of the family name Papacioc, meaning "popă cu cioc" ("bearded priest") ${ }^{5}$. His father was called Vasile and he was a sanitary agent "in charge of six villages". "He was", according to the Father's testimony, "both a veterinary physician, and a doctor for men, and a dentist". His mother was called Stanca, she was of the Mușat lineage, coming from Drăguș Village, situated in the vicinity of Făgăraș. Vasile and Stanca had seven children, two daughters and five sons. Stanca's last child, born when she was 47, was Anghel, namely Father Arsenie. Stanca gave birth to her children on her own, her situation being common, as there were few midwives at that time, and in the villages, more often than not, women gave birth like Stanca. Father Arsenie's mother also experienced the pain for the loss of her first child, who was only a year and ten months old, right on the day when she was giving birth for the second time. "You can realize what my poor mum was feeling", later on Father Arsenie remarked, "one dead on the table and she was in birth

\footnotetext{
${ }^{1}$ First, I evoked the personality of Father Arsenie Papacioc at the meeting of the students from the Faculty of Orthodox Theology and Education Sciences of "Valahia" University, a meeting organized during the period 15 16 May 2017, on the topic Religious Art in the Service of the Promotion of the Christian Spirituality Values. Forms of Resistance of the Romanian Orthodoxy against Totalitarianism (Arta religioasă în slujba promovării valorilor spiritualității creștine. Forme de rezistență ale Ortodoxiei românești în fața totalitarismului), then during the spiritual evenings organized by Stelian Gomboș at Saint Anthony Parish of Bucharest (Titan neighborhood), an event that took place in the evening of 20 May 2017, and, finally, during the International Symposium organized by the above-mentioned Faculty, during the period 30-31 May 2017, on the topic Theology, Iconography, Testimony - Church Resilience by Culture and Spirituality (Teologie, iconografie, mărturisire - Rezistența Bisericii prin cultură şi spiritualitate).

${ }^{2}$ I consider it a great gift from the world's Saviour Jesus Christ that I met Father Arsenie Papacioc even since the summer of the year 1986, when, as a graduate of the $1^{\text {st }}$ year of high school at the Theological Seminary in Bucharest, I came to Techirghiol, accompanying Ion Filon, administrator of the Seminary at that time, to work at the Priestly Sanatorium situated in the same location as the then "Saint Mary" Skete (now "Saint Mary" Monastery). Since that summer I kept a spiritual relation with Father Arsenie Papacioc, to whom I owe so much.

${ }^{3}$ In the civil records one can find the date 13 August 1914, yet Father Arsenie knew from his mother that he was born on 15 August 1914, a date he declared time and again. Back then, births were not recorded precisely, see Părintele Arsenie Papacioc, Mici îndemnuri spre mântuire, edition supervised by Hieromonk Benedict Stancu, Editura Sophia, București, 2009, p. 7; Sorin Alpetri, Între timp și veșnicie. Viața Părintelui Arsenie Papacioc, second edition, significantly improved and completed, Editura Accent Print, Suceava, 2015, p. 16, note 12 (= Alpetri, Viața Părintelui Arsenie). See also the homage volume Părintele Arsenie Papacioc. 19142014. O sută de ani de la naștere, Editura Basilica, București, 2014 (= Părintele Arsenie Papacioc. 19142014.). In some books dedicated to Father Arsenie one can also meet the date 13 August 1914, yet this thing indicates the editors' intervention, who ignore, willingly or not, the Father's statements, see Părintele Arsenie Papacioc, $O$ clipă inima mi se făcuse cer, edition supervised by Hieromonk Benedict Stancu, Editura Elena, Constanța, 2012, p. 11 (= Părintele Arsenie, O clipă inima).

${ }_{5}^{4}$ Alpetri, Viața Părintelui Arsenie, p. 14.

${ }^{5}$ Alpetri, Viața Părintelui Arsenie, p. 14, note 6.
} 
pains!" Father Arsenie's family was somewhat rich. It had 12 hectares of land, horses that they used to till the fields, cows producing milk, sheep and goat herds, and all kinds of poultry ${ }^{6}$.

On the day when Anghel was born, on 15 August 1914, there was a solar eclipse ${ }^{7}$. The father, when he saw his son, as he had not been present at the time of his birth, said: "The Sun disappeared and my son appeared!",

Anghel's childhood was an ordinary one, namely that of a child grown up in the countryside, in full harmony with his family, but also with nature. "We were seven and we spent our time during our childhood mostly outdoors", Father Arsenie used to say, who considered it a great benefit for any child to grow up in an extended environment, preferably in nature, where he can develop harmoniously physically and spiritually. Moreover, he was born in an atmosphere of reverence to God. "I thank God for the fact that I had Christian parents", the Father noted towards the sunset of his life. "What you have from the family remains for the rest of your life"9. Consequently, Anghel drew close to the Church by himself, around the age of seven, obtaining an "inner presence from God", which he will feel throughout his life ${ }^{10}$. One day he asked his mother why the sheep, before going to sleep, stumps its foot. His mother answered: "It is crossing herself, dear, it is crossing herself". His mother's answer got him thinking: "Therefore, why shouldn't I, too!" 11

Thus, Father Arsenie ponders over existential problems since his childhood, in the context of the ongoing First World War (1914-1918), being endowed with different gifts. He was, for instance, skilled at drawing, which is why he went to the Polizu High School in Bucharest, the Sculpture Section ${ }^{12}$; he also had a sense of poetry, which is why he often answered in rhymes; he also had a formidable memory because he could remember, in his old age, poems learnt by heart during his childhood and adolescence ${ }^{13}$.

Actually, Father Arsenie soon stood out in many respects. Around the age of 13-14, he thought for the first time about becoming a monk, although he had neither known the monastic life until then, nor seen any monastery ${ }^{14}$. In certain circumstances, he could feel in himself a maturity going beyond the number of his years. For example, at the age of 15-16, his elder brother, editor at a magazine, took Anghel as a contributor. In the newsroom, the following problem emerged: "if you take a drop from the sea, you take nothing". Those who were working there argued on this theme for a long while. Then, they asked Anghel, as well, who told them:

\footnotetext{
${ }^{6}$ Alpetri, Viața Părintelui Arsenie, pp. 15-18.

${ }^{7}$ Alpetri, Viața Părintelui Arsenie, pp. 16-17.

${ }^{8}$ Alpetri, Viața Părintelui Arsenie, p. 17.

${ }^{9}$ Alpetri, Viața Părintelui Arsenie, p. 18.

${ }^{10}$ Alpetri, Viața Părintelui Arsenie, p. 26.

${ }_{11}$ Alpetri, Viața Părintelui Arsenie, p. 19.

12 Alpetri, Viața Părintelui Arsenie, p. 24. The great Romanian sculptor Ion Jalea was his colleague (Alpetri, Viața Părintelui Arsenie, p. 24).

${ }^{13}$ See Alpetri, Viața Părintelui Arsenie, pp. 23, 27. His memory was also accompanied by a great attention, as he could remember since the age of just 3-4 that, during the First World War fights, his father would "dig trenches in the ground for them, while hiding the girls in the haystack. From the tranches", he would look up and see the dust from the explosions, and thought he should take care that it should not get into his eyes (Alpetri, Viața Părintelui Arsenie, pp. 17-18).

${ }^{14}$ Alpetri, Viața Părintelui Arsenie, p. 25.
} 
"When they analysed the sea water composition, they took a drop. But the way you ask the question, even if you were to take tons of water from the sea, you would still take nothing. And starting with that moment, they began to consider my opinions" 15 .

At the exhortation of the same brother, Anghel began to read all he could find in the collection The Library for All (Biblioteca pentru toți). He was particularly impressed by the novel The Miserables by Victor Hugo [translated into Romanian], so that he was saying about its main character, Jean Valjean, that he had passed "from hell to heaven". However, around the age of 28, he discovers another reading, namely, the Egyptian Paterikon, observing that "a single event of the «Paterikon» concentrates in it the events of a whole novel, be it even «The Miserables»" 16 . From a young age, Anghel began to demonstrate the gift of guiding men, and when he returned to his village, during his holidays, he was "programmed on houses, today in one house, tomorrow in another, having a schedule established several days previously" $"$. At the same time, he shows from an early age the power to forgive those who were unjust to him, later on remembering them at the preparation of the Proskomedia ${ }^{18}$ for the Divine Liturgy ${ }^{19}$. He practiced several sports [football, swimming, athletics (speed, jumps)], including rugby, being called, for his jumps, during the rugby matches, the Blond Panther. Due to sport, he also developed a friendship with King Mihai I of Romania $(† 2017)^{20}$.

After his military service ${ }^{21}$, Anghel joined the Pyrotechnics Section, the level engineering assistant, at the Faculty of Chemistry in Bucharest, which he graduated in two years. During this time, he joined as a free auditor other courses, including Nae Ionescu's philosophy courses. Anghel joined this Faculty to get a job at the "Malaxa" Arms Factory, named after the rich businessman Nicolae Malaxa, built on the suggestion of King Carol II, near Tohanu Vechi, in the region of Brașov, with the aim of replacing the armament and military technique import from Czechia. At this factory was also working his brother Radu,

\footnotetext{
15 Alpetri, Viața Părintelui Arsenie, p. 26. Actually, Anghel also won a poetical creation contest held by this magazine. He had this poetical talent throughout his life, due to it managing to express in an original manner spiritual realities and exhortations, often using examples, situations and stories found in books from extremely varied domains (Alpetri, Viața Părintelui Arsenie, p. 27).

${ }_{16}^{16}$ Alpetri, Viața Părintelui Arsenie, pp. 26-27.

17 Alpetri, Viața Părintelui Arsenie, p. 29.

${ }^{18}$ It is about the moment of the remembrance or the commemoration of the living and the dead at the Proskomedia.

${ }^{19}$ For instance, he was walking, during a summer holiday, with other young people of the village on the border of Fundata Lake, rich in a sort of mud that was healing many people. A drunken villager drew near him, called Marinache, came to them, accusing them that they had stolen a bell from one of his sheep, which was not true. They denied it, but he ran after them to beat them. The young men ran away, after they had split into two groups. Some ran towards a little hill nearby and Anghel to the lake. Followed by the villager, when he arrived on the border of the water, Anghel took his clothes off and began to swim. The villager ran after him, on the border of the lake, but when Anghel arrived on the opposite border, two people caught him and held him until Marinache arrived, who hit him several times with a twig. When his father and brothers found out, they wanted to punish Marinache, yet, finally, they did nothing against him, because Anghel had forgiven him. Later on, when Anghel became a priest and remembered those of his village at the preparation of the Proskomedia for the Divine Liturgy, the first of them was Marinache (Alpetri, Viața Părintelui Arsenie, pp. 30-31).

${ }^{20}$ Alpetri, Viața Părintelui Arsenie, pp. 33-34.

${ }^{21}$ It took place at Regiment 40 Infantry "Călugăreni” of Bazargic Town (today Tolbuhin, Bulgaria). About Anghel's achievements in the army, see Alpetri, Viața Părintelui Arsenie, pp. 43-49. It is worth noting that Anghel rises to the rank of sergeant, and he is requested to remain in the army, but he refuses. During his military service, which lasted for two years, he also sculpted a roadside crucifix, made of oak wood, which remained at Bazargic (Alpetri, Viața Părintelui Arsenie, pp. 49, 53).
} 
as a foreman ${ }^{22}$. Anghel manufactured the first sample of mercury fulminate in Romania and managed to reduce its manufacturing time to half compared to the Czechs, from whom the armament was imported before the construction of the respective factory ${ }^{23}$.

Due to certain circumstances ${ }^{24}$, Anghel is sent to prison, together with his brother Radu, in the Concentration Camp of Miercurea Ciuc (1938-1940), and after his deliverance (18 April 1940) he went to Zărnești, a locality near Brașov, where he took a job as a lawyer's secretary. For a short while (since August until the beginning of September 1940), Anghel was called to arms at Regiment 40 Infantry, situated at Bazargic, in Bulgaria. During that time, Southern Dobruja (Cadrilater) was handed over. Anghel reacted, protesting against the handing over of this region without any fight, but he was "incarcerated". Returning to Zărnești, Anghel was appointed head of the Legionary Movement for the Zârnești small rural district, namely for the county subregion including thirteen localities, then he was elected mayor of Zărnești Town (October 1940) ${ }^{25}$. Being just 26, he was the youngest mayor in Romania (1940-1941) ${ }^{26}$.

Following the "legionary rebellion" of January 1941, during which mayor Papacioc had been involved in no armed incident at all, the new authorities issued a warrant on his name. He presented himself in front of the authorities willingly, being condemned to six years of correctional prison. He spent only several months in Braşov Penitentiary (until August 1941), then he was freed as he requested to go to the front ${ }^{27}$.

For the period of the years 1941-1946, I shall return with details in the second part of this study, and for this reason I shall move on to the moment when Anghel Papacioc took his monastic vows, namely after his deliverance from the Aiud Prison, on 8 September 1946 . He had been imprisoned by Marshal Ion Antonescu's regime and was set free by the communist regime.

As he himself confesses, Father Arsenie had vowed, together with a high school friend, to go both of them to the monastery, when they were 13 years old. His friend got married, yet he cultivated his promise, both when he was in prisons, and when, being free, he enjoyed professional success and social recognition. All these made him affirm that "at the monastery you need to go as a winner, not as a loser" ${ }^{28}$. His mother, Stanca, had not really agreed to this desire that he had, yet she had moved to the Lord while Anghel was in the Aiud Prison. His relatives did not agree to his decision either, but he did not let himself influenced, regarding his joining the monastic life as the reaching of "the summit from which we can see much farther, [perceiving] the other world, where self offering means living in the spirit of God"29, thus going beyond belonging to any kind of ideology.

It was 13 January 1947 and Father Arsenie recalls:

\footnotetext{
${ }^{22}$ Alpetri, Viața Părintelui Arsenie, p. 50.

${ }^{23}$ Alpetri, Viața Părintelui Arsenie, p. 51. As a reward, he received a bonus, and this salary increase allowed him to afford a Ford with two drivers. The car number was 144 on the level of Romania, namely this was the $144^{\text {th }}$ car in Romania (Alpetri, Viața Părintelui Arsenie, p. 51).

${ }^{24}$ They will be shown in the second part of this presentation, highlighting Father Arsenie's prison years, detention places etc.

${ }_{25}$ Alpetri, Viața Părintelui Arsenie, p. 59.

${ }^{26}$ Alpetri, Viața Părintelui Arsenie, p. 60. About Anghel's feats, in the context of the Vienna Award (1940), see Alpetri, Viața Părintelui Arsenie, pp. 60-65.

${ }^{27}$ Alpetri, Viața Părintelui Arsenie, pp. 66-68.

${ }^{28}$ Alpetri, Viața Părintelui Arsenie, p. 90.

${ }^{29}$ Alpetri, Viața Părintelui Arsenie, p. 92.
} 
"I went to the Patriarchate to honour Saint Demeter. These were the first holy relics I was honouring, I was very moved, yet I had not lost my senses. When I went out of the church and I saw the free sky, I felt such a thrill inside, that I felt I could jump into that free sky, I had that foolishness for Christ. And I was not mistaken!" 30

This decision was reinforced to him by several signs:

1) He had been asked by a colporteur to give a book to the shop assistant from the book shop that was "down the street leading to the Patriarchate". He did not know the shop assistant, and in front of the shop there were two women. He gave the book to the shop assistant and, going some 30-40 meters away, one of the women came after him, telling him that the respective shop assistant was calling him.

"I went back to him, he handed over a book to me and said: "Keep your promise!" This was all that he said. You can realize, I did not know him, he did not know me, he did not know what I was thinking, what my most secret promises were. This was yet another sign that I needed to go on";

2) As he was walking down the street, a photo adhered to the sole of his foot. Lifting it, he saw on it a representation of the Turin Shroud. Anghel considered this fact as yet another sign that he needed to continue "on the road he had set on", and he kept this photo throughout his life in a Small Euchologion (Aghiasmatar), a book that he always took with him;

3) At the same time, Angel met on the street his former army captain, who had become a major in the meantime. He proposed to him to remain in the army, but Anghel refused, letting him know that he wished to become a monk ${ }^{31}$.

All these events and the way he left for the monastery represent what Father Arsenie affirmed after years:

"I left for the monastery out of foolishness for Christ. I went to become a monk with a lot of zeal, yet if there is no foolishness for Christ, you cannot resist. Here you lose yourself in order to be able to find yourself, in an angelic position",32.

Remarkable is the itinerary covered by Anghel Papacioc, which I shall present in brief, which could be the topic of another study. He first goes to Frăsinei Monastery, where he is not received, the old starets Simeon telling him:

"I won't take you, brother. I see you are a little more educated and I cannot ask you to take care of the oxen. And then, what will the brothers say: you are keeping this one in the office, while you are asking us to do the hard works!"33

From Frăsinei he left for Cozia Monastery, where he is received (15 January 1947) ${ }^{34}$ and he is entrusted the mission of verger ${ }^{35}$. Many things marked him there, including the veneration of the Holy Relics of Saint Pahomie, who had been a hermit in those places ${ }^{36}$. The Security had him under permanent surveillance at Cozia, having him declare any travel and checked almost monthly. During that period, brother Anghel and his starets, Father Ghermano (Gherman Dineață), were appointed to teach the discipline Education at the

${ }^{30}$ Alpetri, Viața Părintelui Arsenie, p. 93.

${ }^{31}$ Alpetri, Viața Părintelui Arsenie, p. 94.

${ }^{32}$ Alpetri, Viața Părintelui Arsenie, p. 94.

${ }^{33}$ Alpetri, Viața Părintelui Arsenie, p. 95.

${ }^{34}$ Părintele Arsenie, $O$ clipă inima, p. 11.

${ }^{35}$ Alpetri, Viața Părintelui Arsenie, pp. 96-97.

${ }^{36}$ Alpetri, Viața Părintelui Arsenie, pp. 98-99. 
school set up in the vicinity of Turnu Monastery. Brother Anghel taught the students About Christ (Despre Hristos), for a trimester, after which the school director required him to change the topic and teach about communist materialism. Brother Anghel refused and resigned, in exchange, the starets accepted compromise for a salary of 200 lei, which represented an important sum during that time. In front of this situation, brother Anghel had the courage to reprimand his starets: "How did you accept, Father Starets, to abjure Christ?" Since that moment, the starets changed his conduct towards Anghel, whom he was calling an angel (in Romanian: inger). He moved him from his cell into one that had a stone wall washed by the waters of the Olt River, so that in winter the entire wall got full of ice. Although Anghel had already proved his spiritual maturity, and the Fathers of Cozia Monastery and even the Starets of the nearby monasteries often came to him for advice, Father Ghermano, to get rid of him, sent him to Comanca, a locality situated two kilometres away from Caracal. There was a 300 hectares estate, belonging to six monasteries, each monastery sending, in turn, a monk or a nun, to oversee the estate management. Among the six monasteries there was also Tismana. The Starets of this monastery, Father Gherasim Iscu, when he saw Anghel there, reproached the starets of Cozia: "How can you keep such a man here?!" He even proposed Anghel to come to Tismana, yet he answered that he is not going anywhere without his starets' blessing ${ }^{37}$.

"Usually, the brothers would stay at Comanca for one month", Anghel stayed there for 16 months, finally obtaining Father Ghermano's blessing to go, after he had saved the wheat harvest of the six monasteries, which the communists wanted to take ${ }^{38}$. In August 1948, Anghel went to Tismana Monastery, where he remained only for a day, because Father Starets Gherasim Iscu sent him to the Cioclovina Skete. There he lived on his own, for five months, his mission being to take care of twenty beehives. The spiritual life at the skete was not devoid of temptations, to which one can add the communists' attempts to arrest him. Thanks to the wolves, he escaped the arrest, but Father Gherasim Iscu did not, and so he passed to the Lord in prison ${ }^{39}$. Brother Anghel was proposed by the new starets of Tismana for the tonsure in the monastic life. The exarch of the monasteries in the Archiepiscopate of Craiova, coming to inspect the skete, even proposed him as a spiritual counsellor of the Seminary of Mufleni, Craiova. Bishop Firmilian approved the appointment, yet the Security was against it, with the result that Anghel was obliged to leave the Archiepiscopate of Craiova $^{40}$.

In January 1949, brother Anghel was at Sihăstria Monastery, where he had arrived on the advice of Father Gherontie Bălan, an acquaintance from Cozia whom he met once more in Bucharest. Father Cleopa Ilie, the starets of the monastery, ordered that he should no longer be called "Brother" Anghel, but "Father" Anghel, because he had noticed that he had a great influence over the believers. For this reason, Father Cleopa let him stay on his chair

\footnotetext{
${ }^{37}$ Alpetri, Viața Părintelui Arsenie, pp. 100-101. About the miracles lived here, see Alpetri, Viața Părintelui Arsenie, pp. 101-103. Impressive is the event with a she-goat, which he had taken to feed on its milk. Anghel would go into a barn, where he would pray. Once, entering there as he was used to, this she-goat, which had remained outside, made such noise that he decided to let it inside the barn. He bent its front knees and put the animal by his side during his prayer. The next day, when he entered the barn, at prayer time, this she-goat came by itself, got itself on its knees and stayed there without making any noise. This impressed Anghel, who would take advantage spiritually of any situation (Alpetri, Viața Părintelui Arsenie, p. 102).

${ }_{38}$ About this episode, see Alpetri, Viața Părintelui Arsenie, p. 103.

${ }^{39}$ Alpetri, Viața Părintelui Arsenie, pp. 104-105.

${ }^{40}$ Alpetri, Viața Părintelui Arsenie, p. 106.
} 
from his cell porch, entrusting him with the mission to teach people in his absence ${ }^{41}$. Standing out for having attained a special spiritual height, although just a rassophore ${ }^{42}$ (for two years), Anghel was sent alone in the wilderness, according to a secret council of the most advanced Fathers of Sihăstria Monastery: Cleopa Ilie, Paisie Olaru, Ianuarie, Casian and Macarie. Anghel had pre-tasted "the sweetness of the wilderness" at the age of 27, when he stayed for a few months by the side of a hermit Father in the Piatra Craiului Mountains ${ }^{43}$. At his departure for the second experience of the living in the wilderness (the winter between the years 1948-1949, therefore at the age of 34), Father Cleopa gave him a bag full of bread crumbs, and Father Paisie 18 pieces of sugar, whose "spiritual sweetness" was felt by Father Arsenie throughout his entire life ${ }^{44}$.

After a while, brother Anghel was sent, as obedience, to the Biblical Institute of Bucharest. In the morning he was a sculptor at this Institute, and in the afternoon he was a verger at Antim Monastery, where he also had his cell. During this time, he knew the important representatives of The Burning Bush Movement (1945-1948), like the Fathers Benedict Ghiuș, Sofian Boghiu, Petroniu Tănase, Agaton Tudor (Sandu Tudor) etc. or the intellectuals Alexandru Codin Mironescu, Paul Sterian, the composer Paul Constantinescu, the writers Vasile Voiculescu and Ion Marin Sadoveanu, the architect Constantin Joja, the professor Alexandru Elian and many others ${ }^{45}$. The tonsure in the monastic life took place on the day of 26 September 1949, at Antim Monastery, yet on behalf of Sihăstria Monastery. Father Sofian Boghiu read the prayers of the respective service, Father Benedict Ghius, tonsured him, and Father Tănase Petroniu, who drew sorts for his monastic name (Arsenie), was his God-father in his monastic life ${ }^{46}$.

Father Cleopa Ilie was, during that time, the starets of Slatina Monastery, where he wanted Father Arsenie. Things were so arranged, by the divine oikonomia, that Father Arsenie left for this monastery, in the month of June of the year 1950. In the meantime, he is ordained deacon at the Calamfidești Monastery, near Rădăuți, and on 26 September 1950, so, exactly one year after his tonsure as a monk, he is ordained as a priest at Agafton Monastery, near Botoșani ${ }^{47}$. Father Cleopa would say: "I have proposed him for priesthood. He was as clean as he had come out of his mother's womb!"48 Immediately after having received the Holy Mystery of Priesthood, Father Arsenie was appointed confessor and professor at the "Nicodemus the Sanctified" ("Nicodim cel Sfințit") Seminary of Neamt Monastery (1950-1952) ${ }^{49}$.

After the episode of his arrest (December 1951), Father Arsenie returned at Slatina Monastery, where he was in 1952. Given the Security pressures, Father Cleopa and Father

\footnotetext{
${ }^{41}$ Alpetri, Viața Părintelui Arsenie, p. 107.

42 Namely a robe-bearer.

${ }^{43}$ Alpetri, Viața Părintelui Arsenie, p. 111.

${ }^{44}$ Alpetri, Viața Părintelui Arsenie, pp. 111-112; Iată Duhovnicul. Părintele Arsenie Papacioc, vol. 2, edition arranged by Hieromonk Benedict Stancu, Editura Sophia, București, 2006, pp. 26-27 (= Iată Duhovnicul, vol. 2); Arhim. Arsenie Papacioc, Epistole, Editura Accent Print, Suceava, 2015, p. 225.

${ }^{45}$ See Alpetri, Viața Părintelui Arsenie, pp. 113-115.

${ }^{46}$ Alpetri, Viața Părintelui Arsenie, pp. 116-117. Great was his joy when he noticed that Saint Arsenios is celebrated on 8 May, as Saint John the Evangelist, also celebrated on the day of his tonsure as a monk, making him say to himself: "The Apostle of love is following me!” (Alpetri, Viața Părintelui Arsenie, p. 117).

${ }^{47}$ Alpetri, Viața Părintelui Arsenie, p. 118.

${ }^{48}$ Alpetri, Viața Părintelui Arsenie, p. 118, note 142

${ }^{49}$ Alpetri, Viața Părintelui Arsenie, pp. 120-121; Părintele Arsenie, O clipă inima, p. 12.
} 
Arsenie withdraw for two years in the Stănișoara Mountains (1952-1954) ${ }^{50}$. The two went out of the wilderness on the order of Justinian Marina the Patriarch, pressed by the communist regime, which was accusing the monks of the wilderness that they were giving help to the people who opposed the respective regime. They went to Slatina Monastery ${ }^{51}$, then to Bucharest (June 1954), being called by Justinian the Patriarch, who hosted them in the Palace, to save them from prison ${ }^{52}$. Father Arsenie constantly appreciated Patriarch Justinian, about whom he would say that he was "very brave", and whom he personally defended against the accusations that he would have been the man of the regime, as he had understood "his cautious and intelligent attitude" in front of the communist regime. "War is a game of intelligence, yet war is still war", as Father Arsenie would say ${ }^{53}$. The Patriarch sent the two Fathers at the monasteries Țigănești, Pasărea, Căldărușani, Suzana, Zamfira and Cheia, to reinvigorate the spiritual life. At Pasărea Monastery they were arrested, during the service of the Mystery of the Holy Oil, but they were freed by the nuns, over a hundred, arrived with working tools at the Police Section ${ }^{54}$.

Father Arsenie considered it inadequate for them to go from monastery to monastery, thus ignoring the local spiritual fathers. On his proposition of having a monastery where the two could live and be found by anyone for advice, Slatina Monastery was chosen, where the two had also been before. Father Cleopa was appointed starets, and Father Arsenie hegumen (1955), while around them emerged a community of 120 dwellers ${ }^{55}$. Due to these monks' training, of whom many had, later on, an important role in the life of the Church, Slatina Monastery was called Spiritual Academy (Academie duhovnicească), and the local metropolitan also put under their spiritual supervision other monasteries, namely Sihăstria, Sihla, Râșca, Rarău and Cămârzani, so that all of them, having Slatina Monastery as their

\footnotetext{
${ }^{50}$ Alpetri, Viața Părintelui Arsenie, p. 123; Iată Duhovnicul, pp. 35-41. It should be mentioned that Father Arsenie was at his third experience of the wilderness. His first experience took place during the period September 1941 - February 1942, and the second during the winter of the years 1948-1949. In relation to the experience of the wilderness and that of the prison, Father Arsenie affirms: "I have been asked by many where it was harder: in prison or in the wilderness, because I have lived in the wilderness as well. In prison, those who did not believe in God suffered torment and they felt bad. Because there was no invisible force to stop a little the wild impulses of cruelty, of hate, pressing in on man continually. That was missing. In the wilderness, however, the devils one is fighting against were afraid of God and it was easier, despite all the whims of the weather: winter, snow, wild beasts, tension [was present] there, too. Yet, there was, however, a note of freedom. Because you all do not know how precious freedom is and why God left it to us. There is nothing as precious with God as the time he is giving to us to live. Because to breathe in and out is still from God. And then the Lord Christ had great prudence to say that «no hair moves unless such is My will»" [Părintele Arsenie Papacioc, "Nu contează decât maniera în care mori" ("The only thing that matters is the way you die"), in Mărturisitorii. Minuni. Mărturii. Repere, edition supervised by Lucian Voicilă, Editura Lucman, București, 2010, p. 118].

${ }^{51}$ Alpetri, Viața Părintelui Arsenie, pp. 131-132.

${ }^{52}$ Alpetri, Viața Părintelui Arsenie, p. 132.

${ }^{53}$ Alpetri, Viața Părintelui Arsenie, p. 132.

${ }^{54}$ See Alpetri, Viața Părintelui Arsenie, p. 133.

${ }_{55}$ Among them were the Fathers Paisie Olaru, Petroniu Tănase, Emilian Olaru, Gherontie Bălan, Dosoftei Murariu, Iustinian Stoica, Roman Braga, hierodeacon Antonie Plămădeală, future hierarch of the Romanian Patriarchate, monk Marcu Dumitrescu etc. In relation with them was also Father Daniil (Sandu) Tudor of Rarău Skete (Alpetri, Viața Părintelui Arsenie, pp. 135, 138, 151). Father Arsenie was the confessor of Father Andrei Scrima, who, before going to India, came to Slatina Monastery, to take a blessing, see Alpetri, Viața Părintelui Arsenie, p. 147.
} 
headquarters, were called The Community of Saint Theodore the Studite (Obștea Sfântului Teodor Studitul ${ }^{56}$.

In the spring of the year 1955, the Fathers Arsenie Papacioc and Cleopa Ilie took part in the action of the Romanian Patriarchate meant to enlighten and fight the Stylites in Moldavia, but they were also involved, together with other Fathers, in drafting a text directed against the Monastery of Vladimirești ${ }^{57}$.

After the period of detention in Suceava, Bucharest, Jilava and Aiud (1958-1964), Father Arsenie was not received in any monastery. The Metropolitan of Moldavia refused him, due to the fact that Father Arsenie was 50 years old and was under the restrictions of the Decree 410 of the year 1959. In Bucharest, Patriarch Justinian tried to send him to Cernica Monastery, yet the Security, by the Department of Cults, permanently opposed this fact, fearing his presence near Bucharest ${ }^{58}$. Under these circumstances, Patriarch Justinian sent him to the Metropolitan of Ardeal (Transylvania), Teofil, who received him very well and entrusted to him the parish of Filea de Jos Village (1965), and a year later also Filea de Sus Village (1966), where he managed, with his pastoral tact, to bring everyone back to the Orthodox faith ${ }^{59}$.

In July 1967, Patriarch Justinian called Father Arsenie at Cheia Monastery, where he appointed him starets and confessor, so that he was coming back at the monastery after nine years (six years of prison and three years of pilgrimage) ${ }^{60}$. In December 1971, Father Arsenie was moved to Căldărușani Monastery, where he was given the mission of treasurer and cashier ${ }^{61}$. After nine months, in September 1972, he is moved, under the pressure of the Security, at Dintr-un Lemn Monastery, as a confessor and celebrant ${ }^{62}$, where he remained until 9 October 1974, when the communist authorities asked him to go to Cernica Monastery ${ }^{63}$. During that time, some archeological discoveries had been made on the bank of the Ialomița River, also visited by the president of the country Nicolae Ceaușescu ${ }^{64}$. The road was passing by the Balaciu Monastery, then in ruin, and Ceaușescu, seeing it, gave order to be restored also with the State contribution. Father Arsenie, who had been ordained

\footnotetext{
${ }^{56}$ Alpetri, Viața Părintelui Arsenie, p. 134. About the order cultivated at Slatina Monastery see Alpetri, Viața Părintelui Arsenie, pp. 135-136.

57 Alpetri, Viața Părintelui Arsenie, p. 143. For this text, see Iată duhovnicul. Părintele Arsenie Papacioc, Editura Sophia, București, 2010, pp. 228-302. As far as the practice of Father Ioan Iovan of Vladimirești Monastery regarding mass confession and, especially, the frequent Divine Communion see Lect. dr. Ion Marian Croitoru, "Deasa sau rara participare a credincioșilor la Dumnezeiasca Împărtășanie? Dezbatere euharistică în Ortodoxia românească de la jumătatea secolului al XX-lea”, in Euharistie, Spovedanie, Martiriu, Lucrările Simpozionului internațional al Facultății de Teologie Ortodoxă din Cluj-Napoca (3-5 noiembrie 2014), vol. II, coordinators: Vasile Stanciu, Adrian Podaru, Editura Renașterea, Cluj-Napoca, 2015, pp. 363-404; for another analysis of "the spiritual phenomenon" of Vladimirești and Sihastru see also Cristian Vasile, Biserica Ortodoxă in primul deceniu comunist, Editura Curtea Veche, București, 2005, pp. 251-257.

${ }_{58}$ Alpetri, Viața Părintelui Arsenie, pp. 208-210.

${ }^{59}$ Alpetri, Viața Părintelui Arsenie, pp. 212-213.

${ }^{60}$ Alpetri, Viața Părintelui Arsenie, pp. 218-219.

${ }^{61}$ Alpetri, Viața Părintelui Arsenie, p. 230.

${ }^{62}$ Alpetri, Viața Părintelui Arsenie, p. 234.

63 Alpetri, Viața Părintelui Arsenie, p. 249. This change was also due to the Security, which imposed to Patriarch Justinian to move Father Arsenie. In relation to this moment, Father Arsenie affirmed: "The Patriarch protected me, as far as he is concerned, as much as he could. He would say: «This Father defended me in prison, while others were denigrating me, and so how could I move him?» But he had no choice, it was impossible to reach any agreement with the communists" (Alpetri, Viața Părintelui Arsenie, p. 248).

${ }^{64}$ The type of these archaeological discoveries is not specified in the text (Alpetri, Viața Părintelui Arsenie, p. 249).
} 
as a celebrant at Cernica Monastery, was envisioned as overseer of this restoration, which, because of the great costs, no longer took place ${ }^{65}$. However, the Father is appointed, in $1976^{66}$, celebrant and confessor at "Saint Mary" Skete of Techirghiol, later on turned into Monastery, where he will remain until the end of his earthly life (19 July 2011) ${ }^{67}$. The Security informers seized Father Arsenie Papacioc's work, affirming about him that "he enjoyed very much popularity in the county and in the country", many believers "waiting for him at the cell by the church" ${ }^{\circ}$.

\section{GLIMPSES OF FATHER ARSENIE'S EXPERIENCES IN THE COMMUNIST PRISONS}

In the social, cultural and spiritual context of a chaotic epoch deprived of spiritual senses, the young Anghel joined the Legion of the Archangel Michael (Legiunea Arhanghelul Mihail), in 1933, being part of the Iancu Jianu "nest" ("cuibul" Iancu Jianu), which also included Misleanu Commune. He was attracted by the Christian dimension of the Movement, namely by the principles that guided the Legion:

"the knowledge and accomplishment of the commandments of the Evangel, the reading of the Psalter, going to church, the confession of sins, the Holy Communion, fasting, common sense, love for our fellow, charity", all these being "obligatory for those who wanted to call themselves legionaries" $" 69$.

\section{As Father Arsenie testified, the Legion helped him "enormously", promoting}

"an education that was committing you to something. This got me out of a latent state of young man who wanted something and did not know what. And the Legion appeared, with enthusiasm, with valiance, patronized by the Archangel Michael”.

In contact with this Movement, the young Anghel was able to delineate a spiritual ideal for himself, which he followed his entire life:

"We had no other ideal except to be granted by God the happiness to die ripped and persecuted for the spark of Truth that we know we have in us, for whose defense we will set out to battle the rulers of darkness like grim death. This is my motto!"70

Yet, Anghel knew how to maintain a balance, and did not let, as far as he was concerned, the Legionary Movement go above the Christian teching. For this reason, he did not agree to the crimes comitted. "Many mistakes were made in the Legionary Movement,

\footnotetext{
${ }^{65}$ See Alpetri, Viața Părintelui Arsenie, pp. 249-250.

${ }^{66}$ Alpetri, Viața Părintelui Arsenie, p. 262. It has been affirmed that Father Arsenie got to Techirghiol rather due to some intrigues, because he was going to be starets at Cernica Monastery ("Părintele Arsenie Papacioc, apostolul iubirii neamului românesc. Portret", in Atitudini. Indrumar de gândire și trăire ortodoxă, 3/18 (2011), pp. 20-21; Părintele Arsenie, O clipă inima, p. 12, note 1).

${ }^{67}$ On that day I was in Veria (Greece), where I was transcribing, together with Father Matei Vulcănescu, the dialogue that Father Arsenie had had with the Greek Professors Father Georgios Metallinos and Dimitrios Tselengidis, in the morning of the day of June 1, 2010.

${ }_{68}^{6}$ ACNSAS, Fond informativ, dosar 185003, vol. 3, f. 409, apud Alpetri, Viața Părintelui Arsenie, p. 265.

${ }^{69}$ Alpetri, Viața Părintelui Arsenie, p. 38.

${ }^{70}$ Alpetri, Viața Părintelui Arsenie, p. 38. One of the principles of the education received was the keeping of the physical and spiritual cleanliness, namely of the virginity by the unmarried and of the conjugal fidelity by those who had a family. Father Arsenie held on to this principle all his life, and when he was a mayor in Zărnești, being present at a festive opening of a meeting of a Legionary Movement women group, said: "If among you there is any girl who is not a virgin or any married woman who has ever cheated on her husband, she should leave the group at once! It was all that I said and they all shivered" (Alpetri, Viața Părintelui Arsenie, p. 62).
} 
because murder was encouraged", but the Father had no idea about "what was behind these crimes or the inner plotting, which people were talking about". However, Anghel met valuable people in the framework of the Movement, who were going to be models of morality, courage and heroism for many young people, animated by the movement's team work spirit and the exhortation to sacrifice ${ }^{71}$.

During his military service, Anghel interrupted his activity in the Legion, and then he resumed it, while working at the Armament Factory near Brașov. In 1938, Carol II instated a dictatorship, and on the occasion of a reunion of the legionary elite, attended by about 90 persons, he gave the order that about half of them be killed. Anghel had been convoked as well, but due to God's providence he had to be elsewhere ${ }^{72}$.

The first detention of Father Arsenie was as a layman, for two years (1938-1940), in the Prison or Labour Camp of Miercurea Ciuc, following a false denunciation regarding his brother, Radu, whom he was working with at the Malaxa Armament Factory. The denunciation was that Radu could have shut Carol II, while the latter was visiting the respective factory. The investigation took two years, finally revealing the innocence of the Papacioc brothers, Anghel remaining in prison all of this time ${ }^{73}$. However, Anghel turned this situation as well to his spiritual advantage. "I used to go to the attic of the building and pray profoundly..., and the devil would torture me terribly. He came in front of me several times and there I fought him. Yes, I wrestled with him for hours on end", he told a detention mate. He was just 25 years old ${ }^{74}$. Many Legionnaires were imprisoned in the Labour Camp of Miercurea Ciuc, where they took care to maintain an atmosphere of "permanent prayer". They would manufacture little necklace crosses, roadside crosses and icons, and for one hour, day and night, each inmate would pray or read from the Holy Scripture, Psalter, stopping only when he was replaced. "At night, the collective prayer was concluded", according to the testimony of Mircea Eliade, who was also with him in the same labour camp, during the same period, "with an impressive «God is with us» ( $\mathrm{Cu}$ noi este Dumnezeu»), sung by 300 voices" $"$.

The second detention was because of the "legionary rebellion" of January 1941. He took part, as mayor of Zărnești locality, to the Brașov event, where he brought a group of people, yet with no shooting of any bullet ${ }^{76}$. However, he was arrested by the new authorities and condemned to six years of correctional prison, in the Brașov Penitentiary ${ }^{77}$. During this detention, Anghel made a chapel, to which he also sculpted the holy doors. Moreover, he got to become the prison leader, even

\footnotetext{
${ }^{71}$ Alpetri, Viața Părintelui Arsenie, pp. 38-39. About Anghel's participation in the Legionary Movement and its camps, see Alpetri, Viața Părintelui Arsenie, pp. 39-42.

72 Alpetri, Viața Părintelui Arsenie, p. 53.

${ }^{73}$ Radu will be killed by shooting, together with nine legionnaires, in the night of 21 to 22 September 1939, under the false pretext that they wanted to evade. The ten could have included Anghel or anyone else. This is why Father Arsenie would say, later on, to his pain mates from Aiud, that Saint Nicholas kept him safe from death, then, at Miercurea Ciuc. Moreover, after his deliverance, his brother's killer got to be his subordinate. Anghel could have done any thing to him, even kill him, yet he preferred to act by reference to God: "But I thought: if I leave him alone and do not take revenge, God will owe me one; and so I relaxed" (Alpetri, Viața Părintelui Arsenie, pp. 56-58).

${ }_{75}$ Alpetri, Viața Părintelui Arsenie, p. 55.

75 Alpetri, Viața Părintelui Arsenie, p. 55; Fabian Seiche, Martiri și mărturisitori români din secolul XX, Făgăraș, 2010, p. 39.

${ }^{76}$ Alpetri, Viața Părintelui Arsenie, pp. 66-67.

${ }^{77}$ Alpetri, Viața Părintelui Arsenie, p. 67.
} 
"as inmate. How much trust did people have in me and how they were listening to me! Not just in administrative matters, but especially in matters of living and soul. At my door there was a true pilgrimage and I almost had no time to listen to everyone and give the proper advice. I was asking myself, then: what do these people find in me, to be looking for me?"78

This detention only lasted for a few months, Anghel being delivered in August 1941, following his request to go to the front ${ }^{79}$. After his deliverance, Anghel came to Regiment 40 Infantry, to be sent to the front. Father Anghel recalls:

\begin{abstract}
“The soldiers' Distribution Center was in Fetești. I was distributed to battalion 40 with which I was supposed to go to Odessa. I left to join them and before getting to them, the battalion joined the fight and they all were decimated. I was distributed to another battalion, still in Odessa. I left again and before I got there, the battalion joined the fight and again they were all killed. Then I returned to Fetești. The colonel in charge of all these distributions said: «This man is protected by God lest he should die!» And so they discharged me. I wanted to go to the monastery and this is why God was protecting me", Father Arsenie would say, after many years 80 .
\end{abstract}

Nevertheless, the authorities were trying to imprison him again, and even kill him. For this reason, Anghel hid himself in the mountains, first at Piatra Craiului ${ }^{81}$. Living in a cabin, one day a family comes along over there, with just one daughter. The discussions were beautiful, and he confessed to the young family his desire to become a monk. 17 years later, that man will be in the position of torturer of the Father in the trial of the Burning Bush $\operatorname{lot}^{82}$. In the Mountains of Piatra Craiului, Anghel met a hermit, with whom he spent two months. He stayed in the mountains for several months, from September 1941 until February $1942^{83}$.

During the spring of the year 1942, Anghel went at Timișoara ${ }^{84}$, intending to cross the border and go to Germany, because many legionnaires had managed, in this way, to escape the authorities that were after them ${ }^{85}$. His attempt to cross the border did not succeed. It was the month of July 1942. He is caught, arrested and taken to Brașov, where he was judged and condamned to six years of prison. He was 28 years old. He was first taken to a labour camp in Vaslui. The detainees were put into chains with rivets, to prevent their escape.

"I had chains with rivets, not with lock. When my turn came to be enchained, he couldn't. First he was unable to put the rivet, the second time a chain link broke loose, the third time the hammer handle broke. When he saw it, the man hammering the rivets said angrily that he was no longer going to enchain me. I asked him to put the chains on me because, otherwise,

\footnotetext{
${ }^{78}$ Alpetri, Viața Părintelui Arsenie, p. 67.

${ }^{79}$ Alpetri, Viața Părintelui Arsenie, p. 68.

${ }^{80}$ Alpetri, Viața Părintelui Arsenie, p. 68.

${ }^{81}$ Alpetri, Viața Părintelui Arsenie, p. 69.

${ }^{82}$ Alpetri, Viața Părintelui Arsenie, p. 70.

${ }^{83}$ Alpetri, Viața Părintelui Arsenie, pp. 69-71.

${ }^{84}$ During his stay in Timișoara, Anghel did the drawing of Saint Paul the Apostle, holding a sword in his left hand, the Evangel to his busom and the pointer of his right hand pointing to heaven. The explanation of the drawing is written at the bottom, where Anghel put the quotation from Colossians 3: 2: Set your minds on what is above, not on the things that are on earth. During that time, he also read the Egyptian Paterikon, a reading that will be useful to him in the years of prison (Alpetri, Viața Părintelui Arsenie, p. 72). I shall mention that I also have a photo of this drawing, which the Father himself gave to me. Actually, Father Arsenie used to give those who stayed a while in his cell one copy of his drawings. "They were like a business card for him or, maybe, like a lure using which he could catch those sincerely longing for better, for more beautiful" (Alpetri, Viața Părintelui Arsenie, p. 295).

${ }^{85}$ Alpetri, Viața Părintelui Arsenie, p. 71.
} 
they would kill us both. For as long as I prayed inside me, he was not able to put me in chains, but when I saw him getting angry for being unable to enchain me, I stopped praying and then he was able to enchain me"

After an exhausting trip by train, the detainees arrived in Vaslui, where, going down, they went to and fro, and Anghel found himself alone in the train station, with the chains on his hands and feet. In the mean time, a truck had come, and, embarking the detainees, took them to the other part of the town, where the labour camp was.

\begin{abstract}
"I had gotten terribly scared, the Father would recall, because I was afraid lest they should accuse me of attempted escape. Never have I been afraid of freedom as much as then. I went out of the train station quickly and I took directly to the center of the road crossing the city, in the sight of everyone, carring my chains as visibly as possible, in order not to be met hidden among the people and be accused that I wanted to escape. The people were amazed and crossed themselves, but I was minding my way. Since then I remember Vaslui as the longest town in the country, with a single interminable road, at whose end I arrived after a forced and straight march, and my colleagues, when they saw me, jumped with joy that I had not been shot. They loved me a lot and, for the joy of recovering me, held me on their arms for the blacksmith to cut the rivets from the chains"
\end{abstract}

Vaslui was followed by Aiud or Antonescu's prison, where, for "an ideal and much love for the nation", as Father Arsenie confessed, "Church servants and thousands and thousands of believers were under locks and heavy chains, under barbed wire and under the most devilish disdain and human hate, with no signs that they would go out or the slightest relief ${ }^{\prime 88}$. The detainees divided themselves into three groups ${ }^{89}$.

The first group was looking "by all means for a political solution" and wanted "to be informed about everything that was going on in the country". The second group, smaller as dimension, was formed of those "who had become indifferent and were willing to make compromises to get out of prison". The third group was even smaller, called the mystics" group, who assumed their presence in that place, understanding that "it was for their own sins and the sins of the people they loved that they were there and that they have the duty to repent, to pray and to do the Evangel's actions as much as they could"90. This last group included: Anghel Papacioc, Traian Trifan, Traian Marian, Valeriu Gafencu, Virgil Maxim, Ion Ianolide, Marin Naidim, Constantin Pascu, Iulian Bălan, Father Vasile Serghie, Constantin Dumitru (future Father Marcu from Sihăstria) and others ${ }^{91}$. It ought to be mentioned that the Security was considering Anghel as the respective group's "religious theorist" 92 , because he would follow the line drawn by the respective group, namely "a line of Christian and Romanian conduct for all the political detainees, valid not just for the period of Antonescu's dictatorship, but also for the entire life of those imprisoned as model of attitude" 93

\footnotetext{
${ }^{86}$ Alpetri, Viața Părintelui Arsenie, p. 73.

${ }^{87}$ Alpetri, Viața Părintelui Arsenie, p. 73; Pr. Prof. Ion Buga, Minipatrologie contemporană, București, 1994, pp 34-35.

${ }_{88}$ Alpetri, Viața Părintelui Arsenie, p. 74; Arhim. Arsenie Papacioc, Scrisori către fiii mei duhovnicești, Mânăstirea Dervent, Constanța, 2001, p. 142 (= Arhim. Arsenie, Scrisori)

${ }^{89}$ Alpetri, Viața Părintelui Arsenie, pp. 73-74.

${ }^{90}$ Alpetri, Viața Părintelui Arsenie, p. 74.

${ }^{91}$ Alpetri, Viața Părintelui Arsenie, p. 74, note 76.

${ }_{92}$ Alpetri, Viața Părintelui Arsenie, p. 75, note 81.

93 Alpetri, Viața Părintelui Arsenie, pp. 74-75; Virgil Maxim, Imn pentru crucea purtată. Abecedar duhovnicesc pentru un frate de cruce, Editura Antim, 2002², p. 180 (= Maxim, Imn).
} 
Thus, Anghel Papacioc delineates, together with Traian Trifan and Traian Marian ${ }^{94}$, the new conduct to follow, namely, "vertically, that is towards spiritual perfection, as opposed to the horizontal line, which represented the political activity". His opinion will be, therefore, that the Legionary Movement should no longer be overlapped with the Christian teaching, and his argumentation was as follows: "in the political realm often an intervention is needed, in which the authority and moral person of the Church cannot indulge" ${ }^{, 95}$. He saw a collaboration between the Church, by its spiritual people, and the adequate political groups, but the latter ought to be led by living Christians ${ }^{96}$. Consequently, one can notice that Anghel had given up the political activity even since the years 1942-1944, even before the instauration of the communist regime in Romania ${ }^{97}$. On 8 September 1946, he is freed from Aiud, but Romania was under communist regime since $1944^{98}$.

In the prison of Aiud, the mystics' group's life was focused on prayer, both personal and in common (night vigils, the service of The Hours), accompanied by study programme, meditations and exegetic discussions. The seal of their Christian living can be observed as well from the fact that they had a special prayer for their persecutors:

\begin{abstract}
"Lord, Jesus Crist, You, Who have suffered for the entire human nation and have forgiven all those who repent for their sins, make it so that none of the ones who hate and persecute us may suffer anything bad, because of us, at Your judgement. But turn their souls to the conscience of the Truth and give them true repentance, so that Your all-holy Name may be glorified through them as well. As for us, make us worthy to confess You, the true God, Father, Son and Holy Spirit, for the glory of Your Name and the salvation of our souls. Amen!" 99
\end{abstract}

Anghel Papacioc stood out among all the group members, being "exceptionally zelous for attaining the stages of virtuous, pure, holy life, and a fervent animator for hesichastic prayer"100. He "was a monk in lay clothes and when he was praying, he no longer heard and saw anything around him. This state characterized Father Vasile Serghie as well. They were completely absorbed by prayer" ${ }^{\prime 01}$. About what he lived there, Father Arsenie confesses over the years:

"I bless that time. I have spent years in the wilderness, but there I did not have the possibility
to deepen the things of eternal nature, of divine nature, as in suffering. Suffering also united
us. Those of us who have managed to know one another on the cross have remained united.
The image of my prison is together with this small group in which I felt very good. Among
us there was great unity. All of them were ready to die. These people, Gafencu, Trifan,
Marian, all of them, Maxim, Pascu and the others, I would sanctify (canonize) them all. Was,
any of them, better than the other? What matters is the way you receive suffering. I would
sanctify them all, because they were sincere and because they did not hesitate in sacrificing
themselves. They were all sacrificing. They all went, one by one. With a joy hard to explain,

${ }^{94}$ Anghel knew these two even since his mandate as a mayor in Zărnești. Traian Trifan had been the prefect of Brașov, and Marian Traian the mayor of Brașov, Anghel having good relations with both of them (Alpetri, Viața Părintelui Arsenie, p. 61).

${ }^{95}$ Alpetri, Viața Părintelui Arsenie, p. 75.

${ }^{96}$ Alpetri, Viața Părintelui Arsenie, p. 75.

${ }^{97}$ Alpetri, Viața Părintelui Arsenie, p. 75, note 78.

${ }^{98}$ Alpetri, Viața Părintelui Arsenie, pp. 88-89.

${ }^{99}$ Alpetri, Viața Părintelui Arsenie, p. 77; Maxim, Imn, p. 91.

${ }^{100}$ Alpetri, Viața Părintelui Arsenie, p. 77; Maxim, Imn, p. 110

${ }^{101}$ Alpetri, Viăta Părintelui Arsenie, p. 77; Maxim, Imn, p. 107. 
during the Proskomedia I remember them all as fighters, next to the great voivodes of the country" ${ }^{102}$.

We ought to signal that the regime in prisons grew worse beginning with the spring of the year 1943. The detainees were arranged one per cell and supervized rigorously, food got worse, they began to be punished physically, isolated in punishment rooms or at Zarcă, namely in a place considered a sort of "prison in prison", with a tough regime, even an extermination regime. In Zarcă, the detainee was obliged to stand up or stand on the bed side from 5 in the morning till 22 in the evening. If anyone was ill, he had no medical care, and food was scarce. "No grain of bean, no grain of wheat, no piece of potato was allowed. At the window, blocked shutters. There was also a wood ratio: three splints, and in winter, in the morning, the liquid in the sanitary tube had a layer of ice in it" ${ }^{\prime 103}$. Anghel passed through this $\operatorname{Zarcă}^{104}$ several times, impairing his health ${ }^{105}$.

After 23 August 1944, when the Russian troops entered the country, a period of several months followed, dominated by chaos and uncertainty, yet some rights were also granted to the political detainees, who were allowed to stay together in cells according to their preference, read the Holy Scripture, confess their sins once a week, do different works inside, but also outside the prison, and the priests imprisoned had the right to serve in the prison chapel. The detainees in Anghel's group were trying to spend their time in prayers and spiritual conversations.

"To make a program of study, meditation and prayer", Virgil Maxim narrates, at that time a cell colleague of Anghel Papacioc 106 , "we set ourselves meeting hours or days; instead of the guards closing us, we made ourselves inner locks. When you found the door locked, you knew that there the lamp of the heart was lit and was burning for Christ. You returned on the day and at the hour indicated on the door" $" 107$.

For a while, in the cell with the two stayed Father Vasile Serghie as well, who was also their confessor. One day, Father Vasile had a moment of great spiritual torment, realizing that the Holy Mystery of Priesthood was greater than him, and he was trying to avoid accomplishing his service as a priest. Then, Anghel Papacioc, drawing close to him, with tears in his eyes, said to him:
"«O, Father Vasile, now you really are a good Priest! Now, when you live with the conscience of your unworthiness!» «For God's power is made known in powerlessness and God gives grace to the humble». «How good it would be, if each priest were to live with this conscience of his unworthiness. With how much attention, with how much fear and trembling he would accomplish his service of apostle of Christ on earth?!» Falling into each other's arms, they were crying; tears of reassurance and encouraging joy came together on their cheeks... Anghel Papacioc was then mysteriously a priest and a monk!"108

\footnotetext{
${ }^{102}$ Alpetri, Viața Părintelui Arsenie, p. 78; Sfântul închisorilor. Mărturii despre Valeriu Gafencu, adunate și adnotate de Monahul Moise, Editura Reîntregirea, Alba Iulia, 2017², pp. 43-44.

103 Alpetri, Viața Părintelui Arsenie, p. 78; Ion Ianolide, Întoarcerea lui Hristos. Document pentru o lume nouă, edition arranged by Mânăstirea Diaconești, Editura Christiana, București, 2006, p. 47, note 9.

${ }^{104}$ One can see, therefore, that Zarca was not the invention of the communist regime, but of Antonescu's regime, but during the communists' time the conditions become even tougher.

${ }^{105}$ Alpetri, Viața Părintelui Arsenie, p. 78.

${ }^{106}$ He needed permanent help, so that Virgil Maxim remained to take care of him (Alpetri, Viața Părintelui Arsenie, p. 79; Maxim, Imn, pp. 107-108)

${ }^{107}$ Alpetri, Viața Părintelui Arsenie, p. 81; Maxim, Imn, p. 107.

${ }^{108}$ Alpetri, Viața Părintelui Arsenie, p. 82; Maxim, Imn, pp. 115-116.
} 
During the time of this detention, Anghel sculpted different decorative or liturgical items: a beautiful frame, declared "the most beautiful work in the entire prison museum ", which the then prison director took for himself, to frame his portrait, although it was meant for the portrait of Gheorghe Gheorghiu-Dej; several oil icon lamps, including the one that he had in his monastery cell from Techirghiol. Called "the never-sleeping icon lamp ", which he kept permanently lit, the Father explained to those visiting him its symbolism: the candle was delimited in two areas by a belt, which unites and separates, at the same time, the two worlds, celestial and terrestrial, but also the two parts of the human being, soul and body. The belt is considered, in this composition, the symbol of power, which makes the connection respectively between heaven and earth, and between soul and body. The icon lamp is set in a pedestal, put on the wall and which has represented on it some crosses. In the lower area of this pedestal there are three broken crosses, symbolizing the fact that the Truth is persecuted in the world, and the cross above them, situated in the upper area, is straight and overflows with rays downwards, illustrating that the Truth is to prevail in the end, because the fight is from down here, on the earth, but the victory comes from up High, from Heavens ${ }^{109}$.

Anghel Papacioc is delivered from the Aiud prison on 8 September $1946^{110}$, finding the Romanian society, as mentioned also above, under the dominion of the communist regime.

After he received the ordination as a priest (26 September 1950), Father Arsenie was appointed confessor and teacher at the Seminary of Neamț. Followed by the Security, he is arrested, in December 1951. After his deliverance, Father Arsenie went to Slatina Monastery, where he can be found in $1952^{111}$. By their living, the Fathers Cleopa Ilie and Arsenie Papacioc attract many believers. This thing bothered the Security, which began threatening them. Father Arsenie was taken to different Security centres of Suceava County, was thrown into dirty, cold and deserted rooms, under the threat of death. In this context, the two Fathers Cleopa and Arsenie decided to retreat in the mountains nearby the monastery,

\footnotetext{
109 Alpetri, Viața Părintelui Arsenie, pp. 85-86. Anghel's achievements in sculpture were several: the holy doors for the chapel of the Brașov prison (realized during the period 1941-1942); the entrance doors of Turda Bank (before his deliverance from Aiud, in 1946); other holy doors for some churches in Bucharest (after the deliverance of 1964); the ark according to the model of the church of Curtea de Argeș Monastery, at the realization of the project participating several detainees (for their names, see Alpetri, Viața Părintelui Arsenie, p. 86; Maxim, Imn, p. 118), having many sculpture models (about 45-47) realized in miniature by Anghel Papacioc and his disciples Iulian Bălan, Petru Foti and Sebastian Avram. Finished in April 1946, the ark was donated to the "monastery of virgin nuns of Vladimirești", where it actually arrived, yet it disappeared after 1955, when the respective monastery was abolished. It is supposed to have been taken by the Russians. It ought to be mentioned that the ark was seen, in Bucharest, also by the sculptor Ion Jalea, colleague of Anghel Papacioc at the School of Arts and Trades, who exclaimed: "If Anghel had not been imprisoned, he would have prevailed over all of us" (Alpetri, Viața Părintelui Arsenie, pp. 87-88; Maxim, Imn, p. 118). Father Arsenie sculpted his monastic cross as well (1949), much appreciated in the epoch, but also later. He sculpted a similar cross for his God-father in the monastic life, who was Father Petroniu Tănase (Alpetri, Viața Părintelui Arsenie, pp. 115-116). Later, Father Arsenie made a drawing in pencil, representing death under the form of a skull. He multiplied this drawing and gave it to his spiritual sons, to teach them the meaning of death (Alpetri, Viața Părintelui Arsenie, pp. 146-147). At Dintr-un Lemn Monastery, Father Arsenie made a few other drawings: Prefacerea Sfintelor Daruri (The Transformation of the Holy Gifts) or Epicleza (Epiclesis); Crucea din care ies raze de jur împrejur (The Cross Overflowing with Rays) (Alpetri, Viața Părintelui Arsenie, pp. 244-245).

${ }^{110}$ Alpetri, Viața Părintelui Arsenie, p. 88.

111 Alpetri, Viața Părintelui Arsenie, p. 123.
} 
namely in the Mountains of Stânișoara ${ }^{112}$. Father Arsenie spent two years in this wilderness (1952-1954), as mentioned in the first part of this study as well, and what they were living made him exclaim:

\begin{abstract}
"Great is the power of humility! Great is the power of the Holy Fathers! The wilderness means by all means a state from beyond the human being, from beyond high human calculations, because the spiritual life is not a calculated life, it is a life lived without words" $" 113$.
\end{abstract}

The two Fathers' life of hermits was stopped at the pressure of the Security on Patriarch Justinian, who called them to Bucharest (June 1954), to help them escape prison. After a while, the Fathers Arsenie and Cleopa returned to Slatina Monastery (1955). Yet, the activity undertaken here was not on the liking of the Security, which had observed that among the dwellers of Slatina Monastery and of the monastic settlements belonging to it there were also people who had taken part in the spiritual meetings of Antim Monastery, in the framework of the Burning Bush Movement. To this fact one can add two more that reinforced the suspicions of the Security: 1) the presence in Bucharest of the Fathers Arsenie and Cleopa in the homes of Alexandru Mironescu and Constantin Joja, members of the Burning Bush; 2) the consideration of religion as a danger for the communist regime ${ }^{114}$. Consequently, the Security did several arrests, along the year 1958.

Father Arsenie was arrested at Slatina Monastery, in the night of 13-14 June 1958, on a rainy and cold weather. It was past midnight, and the monastery community was at the office of Matins. 98 security officers, descended from three trucks and two cars, endowed with raincoats, armament and strong lanterns, surrounded the monastery and the church. At two o'clock in the morning, when the office came to an end and, according to the order of the monastery, the first to get out of the church was the celebrant, who had been Father Arsenie, and then the starets, the verger opened the great doors and, all of a sudden, flashlights were turned on in their eyes: "Anghel Papacioc, where is he? Here I am, sir!" He was surrounded by arms, to the horror of all the monks, and taken to his monastic cell, and the same was done with all the monks. All night, till morning at 10, Father Arsenie's cell was ransacked. Important documents, copybooks with notes and remarks, many books were confiscated to him. In the morning, realizing the ridicule of the situation they had created, the officers apologized to Father Arsenie, who told them: "The mountain quivered and a mouse came out" ${ }^{\prime 15}$. Together with the Father was also arrested brother Constantin Dumitru (future Father Marcu), being taken to Suceava, where the hearing and the research of the materials taken from the cell began. Initially, they accused Father Arsenie of having had connections with the partisans in the mountains, yet, finding no evidence, they continued to search through his copybooks. After the research, they put him in a room that had an area of one square meter and was about five meter tall. Because of a chair that was there, he could not move and he was dressed only in his robe. He had to sleep on the concrete floor, because on that chair it was impossible ${ }^{116}$. On the second day, the detainees who were in Suceava

\footnotetext{
${ }^{112}$ Alpetri, Viața Părintelui Arsenie, p. 123.

${ }^{113}$ Alpetri, Viața Părintelui Arsenie, pp. 124-125. About Father Arsenie's living in this wilderness, see Alpetri, Viața Părintelui Arsenie, pp. 124-132.

${ }_{114}$ Alpetri, Viața Părintelui Arsenie, pp. 153-154.

115 Alpetri, Viața Părintelui Arsenie, pp. 155-156; it is a paraphrase to the verse Parturient montes, nascetur ridiculus mus of Horace's Ars poetica, see Mic dicționar enciclopedic, Editura Enciclopedică Română, București, 1972, p. XXIII.

${ }^{116}$ Alpetri, Viața Părintelui Arsenie, p. 157.
} 
were put in a truck, blindfolded, and transported to Bucharest, cramped and without the possibility of making any move. In Bucharest, the Father was imprisoned in the Security cellars and, in very tough conditions, the investigation began ${ }^{117}$. Father Arsenie never detailed the torments endured in prison, and his expression, "how unbearable was the investigation", hid in it those sufferings that cannot even be described, thought or understood by those who did not live them ${ }^{118}$.

Father Arsenie's hearings took 90 days, being accompanied by terrible pains and tortures, to find out something from him by force.

"For me", Father Arsenie confessed, "who was better known, it was more difficult, because they wanted me to tell on others as well, to judge and imprison them, too. But I did not do such a thing, God forbid!"119 "They would kill you and beat you, only to say like them". Touching are Father Arsenie's thoughts and experiences in those moments: "It was the pain that you were looking at your dangerous fellows, because they had no fear of God. And I was looking at their loss. Because I was no longer wondering about the problem of my life, the way they had started to slap, and to hurt, and to accuse, it was impossible to think that you were going to live. And then you accepted death by all means. And then you no longer suffered the chains... You were saddened by the fact that it was your fellows who were doing these things. I, who in a way had known the fight against the devil previously, said that «these are more dangerous because they have no fear of God... the devil had fear of God!» 120 And I had to bear by all means that my enemies are my fellows. If you are the man of God, He knows about anything and the more you let yourself in His will, the more He will defend you. But surely you, too, all the more you need to love God and your fellow. And one cannot say that my fellow is my enemy. These spiritual states were coming like thunderbolt through your heart and through your reason. But, indisputably, those were the elements that were keeping you present in every moment. But one cannot do without sacrifice. One cannot do without the cross, this was what it was, this is what I recommend and this is how I want to live by all means. And cross means bearing what you do not like! People's great mistake in the world is that they will not bear suffering and do not understand that it is the only action, the only preoccupation, the only living against everything that is bad from under the devil's patronage" $" 121$. For this reason, Father Arsenie affirmed: "Nothing helped me more than suffering in life. Only suffering is the supreme chair of theology. I am sure that the angels were jealous of us, because they do not have this suffering exceeding our nature" ${ }^{122}$.

\footnotetext{
${ }^{117}$ About the methods used, see the Presidential Commission for the Analysis of the Communist Dictatorship in Romania (Comisia Prezidențială pentru Analiza Dictaturii Comuniste din România), Raport final (Final Report), București, 2006, http://media.hotnews.ro/media_server1/document-2007-12-20-2118604-0-raportultismaneanu.pdf (02.01.2018).

${ }_{118}$ Alpetri, Viața Părintelui Arsenie, p. 159, note 186.

${ }_{119}$ Alpetri, Viața Părintelui Arsenie, p. 160.

${ }^{120}$ I remember that when I visited the Jilava Prison, guided by Marcel Petrișor, and I was together with Father Georgios Metallinos, participating all together at the International Symposion Moartea martirică (Martyric Death), organized by the "Saint Irene" ("Sfânta Irina") Foundation, during the period 11-12 October 2010, in Bucharest, Father Georgios, heeding the suffering and torments the political detainees had been submitted to, as described by Marcel Petrișor, declared: "Not even the devil has been able to imagine so many methods of torture and terror. Man can become unimaginably evil to man".

${ }^{121}$ Arhim. Arsenie Papacioc, Veșnicia ascunsă într-o clipă, Editura Reîntregirea, Alba Iulia, 2004, pp. $57-58$ (= Arhim. Arsenie, Veșnicia). It ought to be mentioned that one of the investigators was that man who had come, 17 years earlier, at the cabin on Mount Piatra Craiului, with his wife and their daughter aged around 10-12, who had appreciated young Anghel so much back them and had seen him "as an angel", being unable to understand his desire to become a monk, see Alpetri, Viața Părintelui Arsenie, pp. 69-70, 161.

${ }^{122}$ Alpetri, Viața Părintelui Arsenie, p. 162.
} 
Until the investigation was finished and the verdict was pronounced, Father Arsenie was taken to Jilava Penitentiary, where the Burning Bush lot was imprisoned ${ }^{123}$. The trial took two days and they were judged at night, "without defence", as the Father confessed ${ }^{124}$. The reasons of Father Arsenie's condemnation to "20 years of forced labour and 10 years of civic disenfranchisement" ${ }^{\prime 25}$ were: his spiritual living, having the experience of the hesichastic life and of the Jesus Prayer, acts that the communist regime characterized as "mysticism and obscurantist bigotism"; his participation to the Burning Bush Movement, which the same regime considered "subversive association"; the accusation that in his youth he had been a legionnaire, although Father Arsenie had moved away from the policy of the Legionary Movement even since the time of the Aiud Prison, to which one can add the fact that, having joined the monastic life, he had renounced the world and everything in it ${ }^{126}$. After his condamnation, Father Arsenie was taken away from Jilava and led, for the second time in his life, to Aiud. During the first months of prison, the Father was "very grieved" for those he had left outside and who maybe needed him, but, later on, turning his "face to the inside", he observed that also in prison there "were so many people with the same needs and the same life as those outside" ${ }^{\prime 27}$. When Father Arsenie arrived at Aiud, the penitentiary was going through a series of changes, delineated especially after the year 1962 and whose aim was to begin an action of "homicide" from a moral perspective of the political detainees, correlated to the "extermination by hunger" or by the punishment of the detainees in the terrible "isolation rooms" 128 . This action will be called "the reeducation from Aiud", and at its center was the destruction of all the values, aiming to make the detainees utter blasphemy against the Christian teaching and the Church, to make them abjure Jesus Christ and to make them admit their docility to the communist ideology ${ }^{129}$.

Many years later, Father Arsenie affirmed that only God made him come out alive from the prison of Aiud, transformed into a sort of monastery in which some even attained

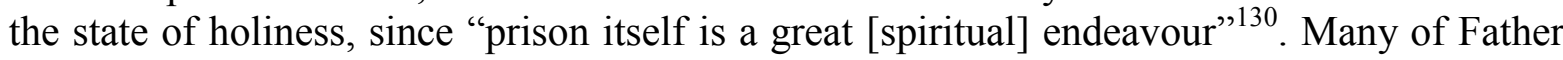
Arsenie's recollections are memorable, yet, to make a profitable use of time, I shall remind of just one. Father Arsenie served the Divine Liturgy daily, managing to improvise, simply and practically, all the necessary things. Instead of epitrachelion, he made a rope chain, which, in the morning, before starting the office, he would bless and pass with a lot of piety over his neck, and after having finished the office, he would wind around a button of his coat. The fireplace took the place of the Holy Table, and the Holy Cross was made up of two

\footnotetext{
${ }^{123}$ Among those imprisoned and who were part of the respective lot there were: Hieroskemamonk Daniil Sandu Tudor (Alexandru Teodorescu), the Fathers Arsenie Papacioc, Benedict Ghiuş, Adrian Făgățeanu, Roman Braga, Dumitru Stăniloae and Sofian Boghiu, the painter Felix Dubneac, the doctors Vasile Voiculescu and Gheorghe Dabija, the students Văsâi Gheorghe, Nicolae Rădulescu, Emanoil Mihăilescu and Dan Pistol, the scholar Alexandru Mironescu and his son Șerban [Alpetri, Viața Părintelui Arsenie, p. 164; Ahim. Andrei Tudor, Mariana Conovici, Iuliana Conovici (ed.), Am înțeles rostul meu... Părintele Arsenie Papacioc în dosarele Securităţii, Editura Humanitas, București, 2014, p. 122 (= Am înțeles rostul meu...)].

${ }^{124}$ Alpetri, Viața Părintelui Arsenie, p. 165.

125 Alpetri, Viața Părintelui Arsenie, p. 166. Finally, the Father was condemned to 40 years of prison, out of which 20 years served (Alpetri, Viața Părintelui Arsenie, p. 167).

${ }_{126}$ Alpetri, Viața Părintelui Arsenie, pp. 165-166.

${ }^{127}$ Alpetri, Viața Părintelui Arsenie, p. 168.

${ }^{128}$ Vezi Alpetri, Viața Părintelui Arsenie, pp. 172-173.

${ }^{129}$ Alpetri, Viaţa Părintelui Arsenie, p. 169; see also Demostene Andronescu, Reeducarea de la Aiud. Peisaj lăuntric. Memorii şi versuri din închisoare, Editura Christiana, București, 2009.

${ }^{130}$ Ne vorbește Părintele Arsenie, vol. 1, under the supervision of Archim. Ioanichie Bălan, Editura Episcopiei Romanului, 1996, p. 98.
} 
minute sticks, kept undone, in order not to let anyone notice, in the inside pocket of his coat. He matched these sticks very carefully on the fireplace, before the start of the office of matins, putting in front of them a thicker stick, in order not to be seen through the peeping hole. The Holy Disk was, sometimes, made of stone, at other times made of a piece of wood, which he wore very carefully in the back pocket of his pants, and a nail was used as spear (liturgical knife). The mug of water took the place of the Holy Chalice in which he put water instead of wine. The Holy Lamb was taken from the upper part of the loaf of bread received as daily share. The only thing he missed was the Holy Antimension. At the beginning, he had had a little piece of the Holy Relics of Saint Mercurius, but he lost them in a search in Jilava. Up to 7 in the morning, when the opening was announced, the office improvised so was ready, and those in the cell communed, one by one, with a piece of bread and a sip of water. The Father would perform the office as in the church, having the conviction that God, seeing their endeavour, could turn the bread and the water into His very Body and Blood. "It was not Holy Communion, but was more than the Anaphora", the Father affirmed when he remembered those times ${ }^{131}$, keeping himself in a state of humility.

While those in his cell enjoyed both the Holy Mystery of the Confession (Penance), and the Divine Communion, those in other cells could benefit, by Morse code, only of the Holy Mystery of the Confession. The Father also told them that if they should get out alive from prison they should go and confess their sins again, while, if they died in the Lord in prison, the Holy Mystery of the Confession, received by Morse code, would remain valid ${ }^{132}$.

Due to the fact that the detainees were moved instead of one another, Father Arsenie had the occasion to stay in the cell with many personalities, although, as he himself confessed, "any detainee was a personality"133. In April 1960, the leadership of the Aiud Prison opened, on the name of Father Arsenie, an individual surveillance file, being put down in it, during the communist regime, all the places of his pilgrimage ${ }^{134}$. The Father was reinforced by the grace of God and managed to overcome suffering beyond any description (for instance, haemorrhoid operation without anaesthesia, having a continual pain for 70 days ${ }^{135}$ ) and isolation in "the most difficult part of the prison, Zarca", created precisely for the detainees to be liquidated using biological means. "Everything was death regime", the Father affirmed, in $1991^{136}$. Those who survived this regime felt "God's help" in their hearts,

131 Alpetri, Viața Părintelui Arsenie, pp. 176-177, 188-189; Iată duhovnicul. Părintele Arsenie Papacioc, Sfânta Mânăstire Dervent, 1999, pp. 16-17. I have received this book from Father Arsenie himself, on 30 December 1999, who also wrote for me the following dedication: "Love the whole world as it is and, surely, the good God will love you as you are".

132 Alpetri, Viața Părintelui Arsenie, p. 178.

${ }^{133}$ Alpetri, Viața Părintelui Arsenie, p. 181.

134 Alpetri, Viața Părintelui Arsenie, pp. 183, 213. Father Arsenie affirmed after 1990: "I have suffered and lived in a continual fear and strain of soul throughout the communist period" (Alpetri, Viața Părintelui Arsenie, p. 213).

${ }_{135}$ Alpetri, Viața Părintelui Arsenie, p. 185.

${ }^{136}$ Alpetri, Viața Părintelui Arsenie, pp. 192-193. It was a noted fact that, in isolation room, people would die in three days. Father Arsenie was put in isolation room for three days on several occasions and did not die, another time he was in isolation room for five days, then for seven days, getting out alive. The Father was punished even to ten days of isolation, starting with the date of 24 December 1963. During this punishment, Father Arsenie lived two miracles: exhausted, after three days spent in that Tartarus, he no longer resisted and sat down, which meant sure death because of the cold air draft, but he felt someone, actually, an Angel, who pulled him by his legs and told him: "Get up, Arsenie, if you do not want to die! Here one cannot sleep! Your time has not come yet!"; at night, the wife of the prison director, Gheorghe Crăciun, had a nightmare, so that he delivered everyone from the ten "punishment boxes" (Alpetri, Viața Părintelui Arsenie, pp. 198-199; Arhim. Arsenie, Veșnicia, p. 62). In another similar situation, when the Father was imprisoned in the cooler room and 
a help without which "one could not have lived. It is very hard, as the Father expressed himself, to be able to say the complexity of the sufferings in heavy chains, in a regime of people completely devoid of heart and of God"137.

At the end of the month of July 1964, Colonel Gheorghe Crăciun himself read to the detainees in Zarcă, namely those who had opposed re-education and the denial of the faith in Jesus Christ, the amnisty decree, saying to them openly: "You those from Zarcă have won!... You have won! You have won! God, you have won!"138 Father Arsenie was freed on 1 August 1964, being no longer imprisoned later on ${ }^{139}$.

Taking into consideration the life of Father Arsenie Papacioc between the years 1938-1964, one can note that he had the experience of the arrest over 40 times and stayed in prison, in total, for 14 years, as he himself confessed ${ }^{140}$.

Until December 1989, the Security permanently kept an eye on Father Arsenie Papacioc, giving him several edifying code names [Călugărul II (The Monk II), Viteazul (The Brave) or Căldăraru (Tinker), Bărbosul (The Bearded) or Izolatul (The Isolated), Duhovnicul (The Spiritual Father) ${ }^{141}$ etc.] and setting all kinds of objectives or traps (infiltration of agents among his spiritual sons and daughters, correspondence censorship, installation in secret in the cell of audio recording means, secret perquesitions in his cell etc.), because they wanted to find out every thing that the Father was thinking and doing, with the obvious aim of restraining or even anihilating his activity and influence in society, under the accusation of betrayal of the communist regime. It ought to be mentioned that in September 1978, the Security decided the conclusion of the personal surveillance file, but preserved the informative surveillance, although it had acknowledged officially that the Father was an authentic monk, who did not aim to do politics under the monastic mask ${ }^{142}$. Actually, the Intelligence Services [the Safety Services (Serviciile de siguranță) and, later on, the Security Services (Serviciile de Securitate)] permanently supervised Father Arsenie Papacioc, even since his first arrest in 1938 and until 1989, with the result that many documents were put together regarding Father Arsenie, summing up over 3,500 pages in the Information Fund (Fondul Informativ), gathered in eight files, namely 15 volumes ${ }^{143}$.

\section{TEACHINGS AND PIECES OF ADVICE FROM FATHER ARSENIE PAPACIOC'S SPIRITUAL HERITAGE}

In 1990, after the fall of the communist regime and the so-called Revolution, there were voices in the press which, referring to the communist period, ostentatiously asked the question: "Where was the Church?" To this tendentious question, Father Arsenie's answer was firm:

felt his end near, but was praying insistently, our Saviour Jesus Christ appeared to him, in divine light and heat, dressed in detainee uniform, in stripes, and was suffering Father Arsenie's "suffering" (Alpetri, Viața Părintelui Arsenie, pp. 199-200).

${ }_{137}$ Alpetri, Viața Părintelui Arsenie, p. 193.

${ }^{138}$ Alpetri, Viața Părintelui Arsenie, p. 204; Anca Bujoreanu, Sfinți martiri și mărturisitori români din secolul $X X$, Editura Adenium, Iași, $2014^{2}$, p. 176.

${ }_{139}$ Alpetri, Viața Părintelui Arsenie, pp. 204-205.

140 Alpetri, Viața Părintelui Arsenie, pp. 72, 129, 205.

${ }^{141}$ Alpetri, Viața Părintelui Arsenie, pp. 232, 250; Am înțeles rostul meu..., pp. 21-23.

${ }^{142}$ ACNSAS, Fond informativ, dosar 185003, vol. I, ff. 256-257, apud Alpetri, Viața Părintelui Arsenie, p. 278; Am înțeles rostul meu..., p. 23.

${ }^{143}$ Alpetri, Viața Părintelui Arsenie, p. 278. To these pages one can add about 2,500 pages in the Criminal Fund (Fondul Penal) and about 150 papers in the Documentary Fund (Fondul Documentar), see Am înțeles rostul meu..., p. 13. 
"in cruel prisons, terrible humiliations, pagan beating, insults full of venom... Hundreds and thousands of priests, living monks, faith brothers, wore heavy chains, chains hammered on anvil in hidden cellars. They pulled our beards out and they were carrying us by the beard as animals by the bridle. They submitted us to terrible hunger intending to exterminate us... They asked us to abjure Christ and His Saints and we did not abjure, God forbid!... They asked for these renounciations insistently and systematically, isolated and put into cooler rooms for them to be able to obtain at least a word against the teaching of our Lord Jesus Christ. And we did not give up... Here was the Church: in prison. Here, where there were thousands of Christians requesting spiritual strenghtening, forgiveness of sins, encouragements and hopes that we were giving to them by knocking on the wall (Morse code). We got out of prisons, those of us who did, happy that we had been helped by the good God... We came out beardless, with no flesh on us, toothless, with our eyes hidden in our orbits, yet still shining. We came out without the look of clerics" ${ }^{2144}$.

In front of these sufferings, Father Arsenie's conviction was, among others, that "any move, any incident is no incident". Each of us "is guided by God so mysteriously and anonymously, to act properly. We have been saved from many misfortunes, each of us, because God ordained that the blow should not hit us" ${ }^{\prime 45}$. Therefore, any man is under God's oikonomia or providence, but, depending on his spiritual position, his life can agree with or be contrary to this divine oikonomia or providence. When he was arrested in 1958 and taken from Suceava to Bucharest, in the Uranus Prison, Father Arsenie was searching for the east in his cell, to pray. "The tram passing down the street was somehow reflected on the cell wall. I kept on thinking how it was that the Sun could reflect on the cell wall, but I was not sure. Then I remembered Alexandru, telling me: "Wherever you turn your face, may God help you!»" He had seven children and no company hired him, because of the obligation to pay a sum of money for each child. Father Arsenie, knowing his situation, would call him to Slatina Monastery, assuring the necessities of life to him.

"And I would give him a bit of everything. All that I was giving him was from my monastic cell. After I had given him, I would look through the cell and I could see that nothing was missing. Alexandru would always tell me a word: «Father, wherever you turn your face, may God help you!»" Then, in prison, the Father remembered these words of Alexandru and said to himself: "it makes no difference where the east is, since Alexandru told me this. Here is what he was prophesying about to me!... And then I started such crying... But I kept my courage throughout the prison years, although hard years followed with the Aiud Prison" ${ }^{146}$.

"Only suffering is the supreme chair of theology", Father Arsenie often affirmed ${ }^{147}$, who considered that sacrifice is

\begin{abstract}
"the essence of Christianism. You sacrifice a pleasure, a pain, a desire, to let there be peace. In order to burn, the wax candle sacrifices wick and wax, while the oil icon lamp sacrifices oil. This is why candles are lit in church, to remind us of sacrifice. One cannot live without sacrifice, one must renounce something to win the day. Peace is four times greater than justice. If you make peace, you win four; if you make justice, you win just one" ${ }^{148}$.
\end{abstract}

Father Arsenie cultivated the string of all the virtues and the varied bouquet of the ascesis actions, yet he always highlighted the "benefactions of charity", which he practiced permanently. He was convinced that

${ }^{144}$ Alpetri, Viața Părintelui Arsenie, pp. 205-206.

145 Alpetri, Viața Părintelui Arsenie, p. 21.

${ }^{146}$ Alpetri, Viața Părintelui Arsenie, pp. 158-159.

${ }_{147}$ Alpetri, Viața Părintelui Arsenie, p. 162.

${ }^{148}$ Alpetri, Viața Părintelui Arsenie, pp. 298-299. 
"charity is one of the great preparations for eternity. To break something out of you. You see, charity is all the Scripture... It has been said that charity rose against justice and charity prevailed... The poor are biblical characters, they will never disappear from the face of the Earth. They are let by God for the rich to have the possibility to be saved as well, by being charitable... God makes many miracles, but you will never see the miracle of God telling lies. If God says that he returns a hundredfold to those who are charitable, this is so. And if this does not happen, it means that the one who gave was not sincere, or gave with a pinch of heart, or gave for who knows what other reasons" $" 149$.

During his military service, the general came for inspection and asked the soldiers, arranged in line, "what battle plan means". No one knew the answer, except for Anghel, who said:

\begin{abstract}
"Battle plan means precise determination of your position, then of the enemy's position, calculation of the distance between you and the enemy and type of armament used". However, "this tactics, I have used it in the spiritual life as well, this is why some have called me: the military monk. First, the precise determination of your position means knowing what position you are fighting your life battle from: that of layman, monk, cleric. The enemy's position refers to the identification of the one you are fighting against. In the spiritual world, the enemy is the devil. For we are not battling, as Saint Paul the Apostle says, against body and blood, but against the powers of darkness. The distance is the one that separates you from the sin nearest to you, because Saint Anthony the Great says: «The greatest sin is the one nearest to you». You are not going to battle a sinful passion that is not waging war against you at the moment, you are going to fight the sin that has dominion over you now. The armament is fasting, prayer, charity, state of cheerfulness, patience, silence, education of love to those around, innocence" "150. "It is through man that man is saved. To be able to save someone, we need to fix ourselves, to be a departure point of our Saviour by which He may save the one next to us. Man through man. It is like a cannon placement. The canon, if it has no placement made of earth, has strong recoil and throws you off, but since it has it stops in its fixed position. So, man is a sort of placement that God makes use of towards other men" 151 .
\end{abstract}

During his stay at Antim Monastery, where he was also tonsured into monk (1949), yet on behalf of Sihăstria Monastery, Father Arsenie had contacts with the representatives of the Burning Bush Movement. An impulse for this Movement was given by Father John Kulâghin, also known under the name of "the Foreigner" ("cel Străin"), who brought with him a rare book on the practice of the prayer of the mind, called Sbornic. Translated in Romanian, the book will circulate in manuscript. Father Arsenie, being a monastery brother, was not for an excessive theorizing of this prayer, which was supposed to be a mysterious one, of the heart. When someone knocked on his cell's door and asked him for the Sbornic, he said: "I will give you gladly!" Yet, he returned with a prayer rope, which he gave to the willing young man, with the exhortation: "Shut up and say!"152

\footnotetext{
149 Alpetri, Viața Părintelui Arsenie, pp. 305-306.

${ }^{150}$ Alpetri, Viața Părintelui Arsenie, p. 44. The same position regarding the need for a battle plan can be met as well with Saint Paisios the Aghiorite: "In the spiritual endeavour it is necessary to mark the weak points of our character, our weaknesses and, then, try to hit there. Because if you know concretely the points the enemy is in, you move safely. You put the map down and you say: «The enemy is here and here. We need to get to obtain these and these points. From there we shall ask for reinforcement, here we need these arms» etc. This means that you can develop a plan. But in order to find out where the enemy is, you need to watch and search, instead of sleep" (Cuviosul Paisie Aghioritul, Cuvinte duhovnicești. III. Nevoință duhovnicească, translation from Greek by Ieroschim. Ștefan Nuțescu, Editura Evanghelismos, București, 2003, p. 153).

${ }^{151}$ Alpetri, Viața Părintelui Arsenie, pp. 44-45.

152 Alpetri, Viața Părintelui Arsenie, p. 115.
} 
Actually, the prayer that Father Arsenie incessantly said was the prayer of the mind or of the heart, also called the Jesus prayer or the prayer of the one thought. God had given to him the gift of this prayer, a fact felt by many of those who came in touch with the Father ${ }^{153}$. I found out about this thing later on, from some recollections of Father Arsenie, even since the time when I was in high school at the Theological Seminary in Bucharest. However, it was only during my studenthood that I was going to become aware of the importance of this prayer for the spiritual life, and the one who spoke to me most convincingly about this prayer was the Professor Virgil Cândea. He spoke to me about the practice of Father John the Foreigner, accompanied by his disciple Leonte or Leontie Calmâc ${ }^{154}$, to give his blessing to those who wanted to practice the prayer of the heart, because, according to the experience of Father John the Foreigner, this prayer cannot be practiced without the advice and blessing of someone who is familiar with it. Following these discussions, I arrived, one day, at Father Arsenie Papacioc, at the exhortation and advice of Professor Virgil Cândea, to ask from him for a blessing to practice the Jesus prayer. I was in a spiritual connection with Father Arsenie since the summer of the year $1986^{155}$. I told Father Arsenie: "Father, I have come to you to give me your blessing to say the prayer of the mind or of the heart! Who told you that this thing is necesary?", the Father asked me. "Mister Professor Virgil Cândea!", I answered. He smiled with contentment and gave me his blessing on the top of my head, saying to me: "Say it once and for all!" I was amazed. "What does this thing mean, Father?" He explained to me: "That is, say it everywhere, even in the bathroom when you go for your natural urges, and any time, and never stop saying it!" Actually, the Father affirmed that "we need, above all, not people who say prayers, more or less regularly, but people who feel the prayer", namely the prayer of the mind or of the heart.

\begin{abstract}
"We have been called to get down not from the mind, but with the mind. The aim is not «the prayer of the heart», but «the prayer of the mind in the heart», because the different forms of understanding, including reason, are a gift from God and need to be used in His service, not rejected. This «union» of the mind with the heart means the restauration of our fallen and fragmented creature, the restauration of our original integrity. The prayer in the heart is a return in Paradise, earnest and anticipation of the time that is to come, something that, in the time that is right now, is never fully accomplished. The Jesus prayer helps us see Christ in every man and each man in Christ, makes out of each of us "a man for the others". The way of the Name is open, generous, not limited by rigid and immutable rules. Prayer is work; to pray is to be working in the highest degree, and for our breath to become one with the Divine Breath, which supports the Universe" $" 156$.
\end{abstract}

According to the experience of Father Arsenie, one ought to be looking for intensely lived prayer moments, during which man's entire being should be concentrated on the meeting with God, so that our feeling may not be stolen to any thought or state of sin.

"I, personally", Father Arsenie affirmed, "am not for the tipikon prayer. That prayer has its special use, especially disciplinarily. Man must not be dogmatic. He must be dogmatic as

\footnotetext{
${ }^{153}$ Alpetri, Viața Părintelui Arsenie, pp. 284-285. For instance, Father Constantin Galeriu affirmed as well this thing about Father Arsenie, see Părintele Arsenie Papacioc. 1914-2014., p. 55.

${ }_{154}$ About the portraits of the two, see Alexandru Mironescu, Calea inimii. Eseuri in duhul Rugului aprins, Editura Anastasia, București, 1998, pp. 29-36.

${ }^{155}$ It was my first holiday as high school student at the Theological Seminary, which I was spending at the Priestly Sanatorium in Techirghiol. I was working at the respective Sanatorium, which was in the same location as the "Saint Mary" Skete. The community was made up of nuns, and the celebrant priest and their father confessor was precisely Father Arsenie Papacioc. See above also note 2.

${ }^{156}$ Alpetri, Viața Părintelui Arsenie, pp. 286-287.
} 
procedure, regarding the desire to become pneumatized. We do not necessarily need a tipikon prayer. We need a continual presence of the heart, this continual state of love, of relation with God, this is the essence of prayer. Because even a deep silence means a deep prayer. And a deep prayer means a deep silence... I am rather for a continual spiritual sparkling. For this reason, ... any moment can be a time and any sigh can be a prayer. Sighing is not done like this: «Ugh!», but you do it to God, as going from the deep towards Him. This is how He will show Himself to us. Because He does not show Himself to a sharp mind..., but only to him who has a clear heart, to him who has the heart towards Him, continually"157.

By these words, Father Arsenie did not annul the tipikon or the external manifestation of faith, but thought, based on his own experience,

\begin{abstract}
"that it is not the multitude of prayers or prostrations which is the most important, «although even those will be written somewhere», but the state of presence (watchfulness) which man needs to have permanently, «because prayer is a necessarily useful means, yet the watchfulness is an aim attained»" 158 . "One must not push the «pedal» of endeavour too much, but an intensity of it. It is not time that can decide, but the quality of the living, by a continual spiritual disposition, not giving room to opaque bitterness; by a sincere and hardpressed regret, which will bring a truer humility, so well received unto forgiveness and so beneficial unto new hopes and revelations above human reason, with which God's love enriches the humble man more than the one strait-laced into a sadness and tough endeavour. The Lord Christ gives Himself with more pleasure to a wounded, yet repentant and humble, heart than to a heart with fasting and prayer, but which of course is asking for its right. Saint Basil the Great says: «The widow or the virgin have no other rank in heaven than the one set by their humbleness!»"
\end{abstract}

In the process of cultivation of the spiritual states, the advice of Father Arsenie is not to neglect the prayer to our guardian Angel. Even since the time spent in the wilderness of the Stânișoara Mountains, Father Arsenie understood the help of the guardian Angel, for which reason he affirmed in his old age (93 years old): "This is it, we have guardian Angel! And it is not just him that is helping us, because they, all the Angels, in their nature are one. And if we are in relation with our guardian Angel, [then] we are in relation with all the Angels, miriads and miriads" 160 . Father Arsenie had acquired many charismata, by which he was helping those fallen in different sins and vices to stand up and not be discouraged:

"Do not get discouraged! Here is the entire subtle fight of the holy «Paterikons» and a great mystery of the spiritual life, namely to stand up, not to remain under the heavy and terrible stone of the fall. I am telling you a great word, according to the spiritual order there is no longer fall, there is only rising. No calamity means anything and nothing is lost as long as the faith remains up, as long as the head is raised again and the soul does not abdicate" ${ }^{~} 161$.

One must note that Father Arsenie cared very much for the Proskomedia and for God's work through it. The Father even would say that the Proskomedia is "the greatest thing in heaven and on earth"162, and "«Liturgy» without «Proskomedia» is a rationalized thing, is a symbol, is no longer a Truth" 163 . Consequently, he would commemorate the diptychs with great responsibility, taking out for each name a particle on the Holy Disk.

${ }^{157}$ Alpetri, Viața Părintelui Arsenie, p. 140.

158 Alpetri, Viața Părintelui Arsenie, p. 141; Ne vorbește Părintele Arsenie, vol. 2, edition supervised by Archim. Ioanichie Bălan, Editura Episcopiei Romanului, 1997, p. 35.

${ }^{159}$ Arhim. Arsenie, Veșnicia, p. 49.

${ }^{160}$ Alpetri, Viața Părintelui Arsenie, pp. 125-126.

${ }^{161}$ Arhim. Arsenie, Scrisori, p. 58; Alpetri, Viața Părintelui Arsenie, p. 269.

162 Alpetri, Viața Părintelui Arsenie, p. 271; see also Alpetri, Viața Părintelui Arsenie, p. 141.

${ }^{163}$ Arhim. Arsenie Papacioc, Singur Ortodoxia, Constanța, 2005, p. 15 (= Arhim. Arsenie, Singur Ortodoxia). 
Personally, I have heard him affirming about the spiritual role of the remembrance of the name and of taking out a particle for each name. "The «Divine Liturgies»" are, according to the conviction of Father Arsenie, "beyond the human mind, the greatest work in God's creation and it, namely the creation, rejoices the most at this [work]" ${ }^{, 64}$. For this reason, suggesting the grace-giving work of the Divine Liturgy, Father Arsenie expressed himself: "Can you realize what it means for a people that it has «Liturgy»? What it means for a people that it has Orthodoxy?"165

Towards the end of the year 2000, Father Arsenie had a surgical intervention, and at the hospital the doctors asked him to tell them a word about medicine. "And I said", the Father tells:

"As technique, I am very pleased with what I see here. But the secret would be this, dear doctors: put the ill man in the situation of participating himself to his recovery as well. If only the ill person believes in the prescription and the medicine given to him, and has to a certain extent trust and great hope of salvation, he can be healed" $" 166$.

"Our Orthodox Church carries us safely on the road of salvation and, because of the depths of the beauty of its teaching, it has many enemies"167. Father Arsenie "saw", by the suffering and tribulations lived, "the power and the truth of the Orthodox Church"168, which he considers "the actual Church".

It is not "divided, people are divided, people have separated themselves. The Church is only one, and that is all, and only the Orthodox Church explains in truth the teaching of our Saviour Jesus Christ"169 "The Truth is Christ, the Orthodox Church, since people have interpreted and will interpret infinitly: the roads, the ways that lead to salvation and it is just one: this one kept on without any change, and even with zeal and with living, the Orthodox Church". It is the "one which patronizes the road to our salvation by all means, in the Orthodox style, as set at the Councils regarding the respective dogmas"170.

About Romania and the Romanian nation, so seriously put to the test, Father Arsenie had a vision of a rare optimism:

"It is a country of divine future. It led no offensive, but only defence wars. Because it is not the one who hits that is victorious, but the one who is patient. The Romanian nation will have, in my opinion, a great mission. Why? Not because it had a Stephen the Great in Moldavia, a Michael the Brave, whom I support with all my soul, in Wallachia ${ }^{171}$ and a Vlad the Impaler. Not for this. But because the Romanian nation did not forget the banging of the bells" $" 172$.

For this reason, the Father's exhortation was that every priest, be he a monk or a priest for the laypeople, should do his service as a priest, because, paraphrasing Saint Philaret of Moscow, "a country stays alive by her spiritual fathers"173.

\footnotetext{
${ }_{165}^{164}$ Alpetri, Viața Părintelui Arsenie, p. 272.

165 Arhim. Arsenie Papacioc, Cuvânt despre bucuria duhovnicească. Convorbiri, Editura Eikon, Cluj-Napoca, $2003^{2}$, p. 91.

${ }^{166}$ Alpetri, Viața Părintelui Arsenie, p. 313.

${ }^{167}$ Alpetri, Viața Părintelui Arsenie, p. 202.

${ }^{168}$ Alpetri, Viața Părintelui Arsenie, p. 202.

${ }^{169}$ Arhim. Arsenie, Singur Ortodoxia, p. 61, 75.

${ }^{170}$ Arhim. Arsenie, Singur Ortodoxia, pp. 9, 34-35.

${ }^{171}$ Named also the Romanian Country.

${ }^{172}$ Alpetri, Viața Părintelui Arsenie, p. 277.

${ }^{173}$ Saint Philaret of Moscow affirmed: "give me good spiritual fathers and I will change the face of the world" (Alpetri, Viaţa Părintelui Arsenie, p. 283).
} 
Although he was proposed many times high ranks in the Church, especially after 1989, Father Arsenie refused them ${ }^{174}$. He represents that spiritual father and Church servant speaking with the Holy Fathers' authority, because he was living in their spirit and prolonged, in this way, their thinking in the present, having in view man's contemporary conditions and needs ${ }^{175}$.

And because we are at a Symposium organized by the Faculty of Orthodox Theology and Education Sciences, I ought to conclude my presentation of Father Arsenie with Christ's exhortation which he felt mysteriously regarding the priestly service, throughout his life:

\begin{abstract}
"When you celebrate the Holy Liturgy ", priest, "thousands of angels fill the Church, adoring Me and glorifying Me. They are My servants, but you are «My priest». You order Me to come down from heaven and be born in your hands. Oh, how your holiness ought to be greater than the Angels' holiness! Together with Me you are a mediator between God and man. Priest, you have the desire to obtain for the people the graces they need! But how could God listen to you, if you are His enemy? I have come to throw fire on earth and you are the ignited torch that will take it in the souls. But how are you to kindle this fire in the souls, if your heart is of ice? My greatness itself depends on your victory. Could I have entrusted to you such great power without giving you the grace to acquire it with diligence?... By dignity I have made you somewhat god, yet I have let on you the burden of the human weaknesses, for My power to be made apparent in your weaknesses. I have made you a destroyer of sin, but leaving you in its danger, a sharer of the supernatural life, but in danger of losing it yourself, out of the fear that My gifts' greatness should not fill you with pride and make you forget that you are nothing... By ordination into priest you were made a partaker of My dignity of head of the Church. The grace of baptism gives you the power to live as a good Christian. The grace of ordination helps you to accomplish your service as a prist with holiness. Before, you were just a simple believer, you were busy first of all with your personal salvation. Now you are a partaker of the dignity of the Head, your heart embraces the whole Church. Your priestly dignity goes above that of the Cherubim and Seraphim, but the grace received by ordination is proportional to this dignity. In My Church I have performed two great miracles: I have created the Theotokos (the Lord's mother) and priesthood. Although a simple creature, My Mother has been made worthy to give birth to a God. And you, My priest, you are a weak mortal. By the grace of ordination, you have been given the power to give birth to Me, with worthiness, on the Holy Altar and in the souls. This grace gives you the right to all the help that you need to be holy and to represent $\mathrm{Me}$, with worthiness, among the people... Pray, entrust yourself to My Mother, the eternal help, the priests' empress! She will help you to listen to My voice. Oh, how bound you are to Me and to My Mother!... Beware of making of the chair of the truth a stage on which to pretend daily your own esteem and to scold the believers. You need to know to scold firmly but gently, without ruining the remedy with the venom of your own lack of patience. Simplicity and benevolence will win more souls for Me than scholarly speeches. Gentleness and humility will give you the key to the most closed hearts... Don't be a small soul, put your trust in the grace you have received at your ordination! Make it bring fruits of "holiness" for you and others! Oh, if only you knew how many graces I decreed for you on the day of your ordination! If only you could understand how many rights your priesthood is giving to you upon My heart and upon the riches it comprises!" 176
\end{abstract}

\footnotetext{
${ }^{174}$ See Alpetri, Viața Părintelui Arsenie, p. 15, note 10.

${ }^{175}$ Mitropolitul Serafim, "Părintele Arsenie - duhovnicul trezviei şi al iubirii”, in Am înțeles rostul meu..., p. 7. Father Arsenie was part of what the Romanian intellectuals, like Alexandru Duțu, called the "pneumatic hierarchy" or, rather, the "pneumatic", namely spiritual, "priesthood", in whose hands was the shepherding of the Church believers during the communist regime (Alexandru Duţu, Ideea de Europa și evoluția conștiinței europene, All Educational, București, 1999, p. 217).

${ }^{176}$ Arhim. Arsenie, Scrisori, pp. 148-152.
} 
In relation to the service of priest, Father Arsenie recommended not just to the priests and monks but also to the lay people to wear a beard, which he considered, based on the confession of "Saint" Clement of Alexandria, as "emanating a great magnetic power and having a special influence on the thinking", being in "close connection with the innermost substrata of faith",177.

"Everywhere, knowledge keeps heaping up, yet to no avail. The Orthodox Church does no press mainly the "knowledge" pedal, but rather the "living" pedal. It has been possible to note that by living you know much and do not know where you know from. And the theologians come, in order to freshen up, to the livers, who are simple according to people's inventory, have no knowledge, but have a continual presence with God. If the branch calls for sap abundantly, it will be given abundantly"178.

Therefore, important is for the believer to be a branch in the wine, namely in Christ, because the Saviour is the Way, the Truth and the Life (John 14: 6). Commenting on these words of our Saviour, Father Arsenie affirmed: "If there is no way, there is no walking, if there is no truth, there is no knowledge, if there is no life, there is no living" "179. During the Lent of the year 2003, Father Arsenie held a conference at the Cultural Centre of Constanța, attended by about 3,000 people. To conclude, the Father said at the end of the conference:

"The Truth, Who is Christ, is the touchstone, it is around this Truth that everything revolves.

To fight this Truth, all sort of philosophies, trends, ideas have emerged, which bring nothing new except for a new vocabulary, new words, but do not clarify anything, because Christ's truth is complete and they do nothing except to hit against this Truth" ${ }^{180}$.

\section{BIBLIOGRAPHY}

[1] Alpetri, Sorin, Intre timp și veșnicie. Viața Părintelui Arsenie Papacioc, second edition, significantly improved and completed, Editura Accent Print, Suceava, 2015.

[2] Andronescu, Demostene, Reeducarea de la Aiud. Peisaj lăuntric. Memorii și versuri din inchisoare, Editura Christiana, București, 2009.

[3] Atitudini. Indrumar de gândire și trăire ortodoxă, 3/18 (2011).

[4] Buga, Pr. Prof. Ion, Minipatrologie contemporană, București, 1994.

[5] Bujoreanu, Anca, Sfinți martiri și mărturisitori români din secolul XX, Editura Adenium, Iași, $2014^{2}$.

[6] Croitoru, Lect. dr. Ion Marian, "Deasa sau rara participare a credincioşilor la Dumnezeiasca Împărtășanie? Dezbatere euharistică în Ortodoxia românească de la jumătatea secolului al XX-lea”, in Euharistie, Spovedanie, Martiriu, Lucrările Simpozionului internațional al Facultății de Teologie Ortodoxă din Cluj-Napoca (3-5 noiembrie 2014), vol. II, coordinators: Vasile Stanciu, Adrian Podaru, Editura Renașterea, Cluj-Napoca, 2015, pp. 363-404.

[7] Duțu, Alexandru, Ideea de Europa şi evoluţia conștiinței europene, All Educational, București, 1999.

[8] Ianolide, Ion, Intoarcerea lui Hristos. Document pentru o lume nouă, edition arranged by Mânăstirea Diaconești, Editura Christiana, București, 2006.

[9] Iată duhovnicul. Părintele Arsenie Papacioc, Editura Sophia, București, 2010.

[10] Iată Duhovnicul. Părintele Arsenie Papacioc, vol. 2, edition arranged by Hieromonk Benedict Stancu, Editura Sophia, București, 2006.

[11] Iată duhovnicul. Părintele Arsenie Papacioc, Sfânta Mânăstire Dervent, 1999.

[12] Mărturisitorii. Minuni. Mărturii. Repere, edition supervised by Lucian Voicilă, Editura Lucman, București, 2010.

${ }^{177}$ Alpetri, Viața Părintelui Arsenie, p. 149

${ }^{178}$ Arhim. Arsenie, Veşnicia, p. 126.

179 Alpetri, Viața Părintelui Arsenie, p. 311.

${ }^{180}$ Alpetri, Viața Părintelui Arsenie, p. 320. 
[13] Maxim, Virgil, Imn pentru crucea purtată. Abecedar duhovnicesc pentru un frate de cruce, Editura Antim, $2002^{2}$.

[14] Mic dicționar enciclopedic, Editura Enciclopedică Română, București, 1972.

[15] Mironescu,Alexandru, Calea inimii. Eseuri in duhul Rugului aprins, Editura Anastasia, București, 1998.

[16] Ne vorbește Părintele Arsenie, vol. 1, under the supervision of Archim. Ioanichie Bălan, Editura Episcopiei Romanului, 1996.

[17] Ne vorbește Părintele Arsenie, vol. 2, edition supervised by Archim. Ioanichie Bălan, Editura Episcopiei Romanului, 1997.

[18] Paisie Aghioritul, Cuviosul, Cuvinte duhovnicești. III. Nevoință duhovnicească, translation from Greek by Ieroschim. Ștefan Nuțescu, Editura Evanghelismos, București, 2003.

[19] Papacioc, Arhim. Arsenie, Cuvânt despre bucuria duhovnicească. Convorbiri, Editura Eikon, Cluj-Napoca, $2003^{2}$.

[20] Papacioc, Arhim. Arsenie, Epistole, Editura Accent Print, Suceava, 2015.

[21] Papacioc, Arhim. Arsenie, Scrisori către fiii mei duhovnicești, Mânăstirea Dervent, Constanța, 2001.

[22] Papacioc, Arhim. Arsenie, Singur Ortodoxia, Constanța, 2005.

[23] Papacioc, Arhim. Arsenie, Veșnicia ascunsă intr-o clipăa, Editura Reîntregirea, Alba Iulia, 2004.

[24] Papacioc, Părintele Arsenie, Mici îndemnuri spre mântuire, edition supervised by Hieromonk Benedict Stancu, Editura Sophia, București, 2009.

[25] Papacioc, Părintele Arsenie, O clipă inima mi se făcuse cer, edition supervised by Hieromonk Benedict Stancu, Editura Elena, Constanța, 2012.

[26] Părintele Arsenie Papacioc. 1914-2014. O sută de ani de la naștere, Editura Basilica, București, 2014.

[27] Presidential Commission for the Analysis of the Communist Dictatorship in Romania (Comisia Prezidențială pentru Analiza Dictaturii Comuniste din România), Raport final (Final Report), București, 2006, http://media.hotnews.ro/media server1/document-2007-12-202118604-0-raportul-tismaneanu.pdf (02.01.2018).

[28] Seiche, Fabian, Martiri și mărturisitori români din secolul XX, Făgăraş, 2010.

[29] Sfântul inchisorilor. Mărturii despre Valeriu Gafencu, adunate și adnotate de Monahul Moise, Editura Reîntregirea, Alba Iulia, $2017^{2}$.

[30] Tudor, Ahim. Andrei / Conovici, Mariana / Conovici, Iuliana (ed.), Am înțeles rostul meu... Părintele Arsenie Papacioc în dosarele Securității, Editura Humanitas, Bucureşti, 2014.

[31] Vasile, Cristian, Biserica Ortodoxă in primul deceniu comunist, Editura Curtea Veche, București, 2005. 